\title{
Carotenoids in the Management of Glaucoma: A Systematic Review of the Evidence
}

\author{
Drake W. Lem ${ }^{1} \mathbb{D}$, Dennis L. Gierhart ${ }^{2}$ and Pinakin Gunvant Davey ${ }^{1, * \mathbb{D}}$ \\ 1 College of Optometry, Western University of Health Sciences, 309 E Second St, Pomona, CA 91766, USA; \\ drake.lem@westernu.edu \\ 2 ZeaVision, LLC, Chesterfield, MO 630005, USA; dgierhart@zeavision.com \\ * Correspondence: contact@pinakin-gunvant.com; Tel.: +1-909-469-8473
}

Citation: Lem, D.W.; Gierhart, D.L.; Davey, P.G. Carotenoids in the Management of Glaucoma: A Systematic Review of the Evidence. Nutrients 2021, 13, 1949. https://doi. org/10.3390/nu13061949

Academic Editor: Dariusz Nowak

Received: 10 May 2021

Accepted: 4 June 2021

Published: 6 June 2021

Publisher's Note: MDPI stays neutral with regard to jurisdictional claims in published maps and institutional affiliations.

Copyright: (c) 2021 by the authors. Licensee MDPI, Basel, Switzerland. This article is an open access article distributed under the terms and conditions of the Creative Commons Attribution (CC BY) license (https:// creativecommons.org/licenses/by/ $4.0 /)$.

\begin{abstract}
Primary open-angle glaucoma (POAG) remains a leading cause of irreversible blindness globally. Recent evidence further substantiates sustained oxidative stress, and compromised antioxidant defenses are key drivers in the onset of glaucomatous neurodegeneration. Overwhelming oxidative injury is likely attributed to compounding mitochondrial dysfunction that worsens with age-related processes, causing aberrant formation of free radical species. Thus, a compromised systemic antioxidant capacity exacerbates further oxidative insult in glaucoma, leading to apoptosis, neuroinflammation, and subsequent tissue injury. The purpose of this systematic review is to investigate the neuroprotective benefits of the macular carotenoids lutein, zeaxanthin, and meso-zeaxanthin on glaucomatous neurodegeneration for the purpose of adjunctive nutraceutical treatment in glaucoma. A comprehensive literature search was conducted in three databases (PubMed, Cochrane Library, and Web of Science) and 20 records were identified for screening. Lutein demonstrated enhanced neuroprotection on retinal ganglion cell survival and preserved synaptic activity. In clinical studies, a protective trend was seen with greater dietary consumption of carotenoids and risk of glaucoma, while greater carotenoid levels in macular pigment were largely associated with improved visual performance in glaucomatous eyes. The data suggest that carotenoid vitamin therapy exerts synergic neuroprotective benefits and has the capacity to serve adjunctive therapy in the management of glaucoma.
\end{abstract}

Keywords: carotenoids; macular pigment; macular pigment optical density; MPOD; lutein; zeaxanthin; meso-zeaxanthin; glaucoma; primary open-angle glaucoma; retinal neurodegeneration

\section{Introduction}

Glaucoma is an optic neuropathy that is characterized by progressive neurodegeneration of the inner retina, including the optic nerve head $(\mathrm{ONH})$ and retinal nerve fiber layer (RNFL), resulting in loss of retinal ganglion cells (RGCs) and characteristic visual field defects [1-3]. It remains the leading cause of irreversible vision loss globally and the projected prevalence of glaucoma is expected to reach 112 million in 2040 [3,4]. In the United States, the National Eye Institute estimates that over 4 million adults will be affected by 2030 and anticipates that the total will exceed 6.3 million in 2050 [5]. Similarly, healthcare expenditures related to glaucoma in the United States have been appraised at USD $\$ 2.5$ billion annually [6]. Owing to the aging global population, the prevalence of glaucoma is expected to continue to rise and will remain a major global health problem.

The most common form of glaucoma in the United States, and worldwide, is primary open-angle glaucoma (POAG) [1]. Intraocular pressure (IOP) remains the only established modifiable risk factor for the incidence and progression of glaucoma [7,8]. Non-modifiable risk factors include age ( $\geq 60$ years of age), race/ethnicity (e.g., individuals of African, Hispanic, or Latino descent), family history of glaucoma, myopia, type 2 diabetes mellitus, and central corneal thickness [9-13]. Current therapeutic approaches are aimed at delaying the disease's progression by lowering the IOP through medical or surgical interventions [14,15]. 
However, a significant portion of patients with POAG still incur progressive glaucomatous vision loss despite maintenance of IOP within the normal statistical range [15].

Although the etiopathogenesis of glaucoma is not fully understood, there is a growing and evidence-based consensus that mitochondrial dysfunction and redox imbalance are likely involved in IOP elevation and the onset of neurodegeneration in the retina. Several theories of IOP-induced injury, including biomechanical deformation of lamina cribrosa and vascular dysregulation, consider overwhelming propagation of free radicals to be a key factor in perpetuating loss of RGCs [16-18]. Thus, an important mechanism in glaucomatous injury likely involves a vicious cycle of sustained oxidative stress whereby inhibition of the endogenous antioxidant defense systems potentiates retinal neurodegeneration [19-25]. Moreover, the retina is known to be particularly vulnerable to oxidative injury and free radical formation, in part due to its extremely high metabolic activity and constant exposure to light [26-28], wherein susceptibility increases with senescence [29-32]. Given the importance of macular pigment for optimal visual performance and maintaining retinal health, herein we review the current evidence in the literature investigating the neuroprotective association between macular carotenoid levels and glaucomatous neurodegeneration.

The body's inherent defense mechanisms against oxidative damage, involving the neutralization of free radical species, rely upon the interplay between both endogenous and exogenous antioxidants to maintain redox homeostasis [21,33]. In particular, antioxidants such as the macular carotenoids lutein, zeaxanthin, and meso-zeaxanthin possess significant antioxidant and anti-inflammatory effects in the retina [34-36]. Clinical benefits in visual performance associated with dietary carotenoid supplementation have been demonstrated in healthy adults [37-40], as well as similar neurodegenerative retinopathies, including age-related macular degeneration [41-43] and diabetic retinopathy [44,45]. Despite similarities in pathogenesis involving sustained oxidative damage in the retina, only a limited number of studies have investigated the relationship between dietary carotenoid intake and pathophysiology in glaucoma.

However, experimental models of glaucomatous injury indicate that the carotenoids lutein and zeaxanthin may play a neuroprotective role against glaucomatous injury in the retina [46-51]. Lutein treatment in murine models of ischemia-reperfusion (I/R) injury was found to be effective in protecting against measures of oxidative and nitrosative stress $[46,47,49]$ and enhance endogenous levels of glutathione (GSH) activity in rat retina [47]. Preliminary findings indicate that carotenoids may exert a synergic neuroprotective effect, at least in part by improving ganglion cell survival in the inner retina $[46,48]$ while limiting activation of apoptotic pathways induced by glaucomatous injury [46,48-52]. Interestingly, not only was lutein treatment found to enhance RGC survival but also exhibited improvements against purported mechanisms contributing to secondary neurodegeneration in glaucomatous pathology [3,51-53].

To date, a limited number of observational studies [54-59] and clinical trials [60-62] have directly investigated the association between macular pigment optical density levels and open-angle glaucoma. Generally, evidence from clinical studies suggests that MPOD levels are reduced in glaucomatous eyes [56] and may be further compromised in relation to disease severity, particularly among those with foveal involvement [57-59]. However, some observational studies were unable to confirm that depletion of MPOD levels is associated with the presence of glaucoma $[54,55]$. The difference in study findings thus mandates a need for a consensus and a summary-generating systematic review of the literature.

\section{Pathophysiology of Primary Open-Angle Glaucoma}

\subsection{Clinical Features of Primary Open-Angle Glaucoma}

The defining features of glaucomatous damage are largely characterized by distinct changes to the $\mathrm{ONH}$ and corresponding visual field defects in consequence of neurodegenerative thinning of the nerve fiber layers $[1,3]$. Biomechanical deformation of lamina cribrosa in response to IOP-related injury can be identified by excavation (or "cupping") of the optic disc, evidenced by progressive narrowing of the neuroretinal rim, and likely 
represents the initial site of RGC injury occurring at the ONH. Furthermore, characteristic patterns of peripapillary RNFL loss with corresponding arcuate visual field defects are common in patients with glaucoma [3].

In open-angle glaucoma, the iridocorneal angle remains visibly open upon clinical examination by gonioscopy, allowing for drainage of aqueous humor through the trabecular meshwork outflow pathway [1]. However, there is often greater resistance to or internal blockage of the aqueous outflow through the trabecular meshwork, causing an IOP elevation. Although IOP remains a strong primary risk factor for glaucomatous damage to the optic nerve and visual field, increased IOP is not required for diagnosis and damage can occur at any level of eye pressure $[1,3]$.

\subsection{Pathogenic Mechanisms of Glaucomatous Neurodegeneration}

Glaucomatous pathology shares distinct features with several neurodegenerative disorders of the central nervous system, largely driven by overwhelming propagation of free radical species from compounding mitochondrial dysfunction with age $[30,63-65]$ and either a tissue perfusion insufficiency or a bioenergetic crisis caused by a disruption in the ATP supply [23,53,66-72]. Consequently, and perhaps by definition, the magnitude of glaucomatous damage and RGC death is likely dependent upon, and determined by, the systemic antioxidant capacity in addition to any factors that may influence the local ocular redox status, and not solely upon IOP-induced injury.

In this regard, proliferative oxidative stressors and inhibition of endogenous antioxidant defenses have largely been considered the engine of neurodegenerative onset [19-23,72-74]. Thus, the mitochondrial redox balance becomes the central battleground for cell survival and worsening mitochondrial dysfunction may further compromise RGC viability $[16,31,65]$. Sustained oxidative injury likely acts as the primary mechanism of glaucomatous tissue damage, wherein it ultimately leads to progressive loss of RGCs and subsequent functional deterioration of the optic nerve. Glaucomatous neurodegeneration occurs primarily by induction of programmed cell death, often proceeding through either intrinsic or extrinsic apoptotic pathways that rely upon caspase-dependent activity $[31,65,75]$. There is evidence of significant oxidative damage in the trabecular meshwork causing resistance to aqueous humor outflow and subsequently an IOP elevation in patients with POAG $[29,76,77]$. Furthermore, the multifactorial nature of glaucomatous neurodegeneration strongly indicates that several interconnected mechanisms are likely to contribute to RGC loss and subsequent visual field defects [2,3,53,78].

Emerging findings suggest that the glaucomatous retina may become an environment hostile to RGC survival, wherein pro-oxidant and pro-inflammatory processes perpetuate glaucomatous neurodegeneration over time. Persistent overwhelming oxidative insult can trigger immunostimulatory activation of the innate immune system, causing a concurrent low-grade inflammatory response in the retina involving resident immune cells $[19,79,80]$. For instance, immunostimulation of the inflammasome oligomerization through purinergic signaling via $\mathrm{P} 2 \mathrm{X} 7$ receptor activation has been shown to play a key role in contributing to RGC toxicity and cell death [81]. Over time, the resultant parainflammatory response, or adaptive immune response to inflammatory stimuli in order to restore homeostatic processes [82], becomes dysregulated and advances into a state of chronic inflammation $[19,79,80]$. Thus, in response to further oxidative insult, the over-activated glial cells, namely microglia, release pro-inflammatory molecules such as tumor necrosis factor alpha (TNF- $\alpha$ ), nitric oxide synthase (NOS), and cyclooxygenase-2 (COX-2) [79,80,83-85]. Retinal injury due to pro-oxidant and pro-inflammatory stressors induced by glaucomatous tissue injury may be further exacerbated by chronic activation of the innate immune system.

Glutamate neurotoxicity has been previously considered among several primary contributing factors sufficient to induce the death of ganglion cells and optic nerve damage in glaucoma. Theories regarding excitotoxicity as a causal mechanism in glaucomatous injury are largely based on seminal findings wherein elevated intraocular levels of the excitatory neurotransmitter were reportedly found in glaucomatous eyes $[86,87]$. However, there is a 
growing evidence-based consensus that is not in agreement with this hypothesis [87-91], and there is substantial evidence that intravitreal glutamate levels are not elevated in humans [89] or animal models of glaucoma [90,91]. Despite this, glutamate is an integral component of the mammalian central nervous system (CNS) and dysregulated excitatory neurotransmission can lead to proliferative excitotoxic cell death in neurons [92-94]. Given that the axons of RGCs are direct extensions of the CNS, glutamate neurotoxicity may still be relevant in glaucomatous pathology, likely contributing to progressive secondary neurodegeneration in response to overwhelming oxidative injury.

Glaucomatous optic neuropathy is marked by a substantial loss of RGCs and their axons, which suggests that progressive damage is not limited to retinal substructures or the optic nerve. Previous reports have corroborated the structure-function relationship between neurodegenerative RGC death and functional vision loss in glaucomatous eyes [95-99]. Correspondingly, the process of transsynaptic degeneration likely exacerbates axonal injury, in consequence of biomechanical stress or a vascular insufficiency, wherein the neurodegenerative cascade, which results in apoptotic death of RGCs, disseminates along the entire visual pathway $[23,53,71,100-103]$. There is a strong line of evidence whereby both Wallerian (anterograde) and retrograde degeneration can be attributed to axonal damage and loss of RGC somas in the human visual system [102]. In this regard, one may presume that for each ganglion cell in the retina, a corresponding neuron is present in the retinogeniculate pathway, and, therefore, a substantial loss of RGCs (i.e., visual field defects) may be indicative of significant neurodegenerative loss at the visual cortex level [104]. In fact, secondary degeneration was observed in the lateral geniculate nucleus (LGN) with corresponding damage to the ONH in primates following artificial IOP elevation [103]. Furthermore, structural magnetic resonance imaging (MRI) studies in patients with POAG have revealed significant neurodegenerative alterations in the LGN and central cortical structures of the visual pathway, as evidenced by shrinkage in the LGN height and volume after region of interest (ROI)-based analysis [105]. Similar neuroimaging studies reported a marked reduction in axonal volume in the optic radiations originating from the thalamus and primary visual cortex concomitant with atrophy of the LGN $[100,105]$. Thus, adjunctive therapeutic strategies must be aimed at simultaneously slowing down glaucomatous damage concomitant with exerting a neuroprotective effect on RGCs in glaucoma.

\section{Macular Pigment Optical Density in the Management of Glaucoma}

\subsection{Role of Macular Pigment Optical Density}

The xanthophyll carotenoids lutein, zeaxanthin, and meso-zeaxanthin play a crucial role in preserving retinal health while maintaining optimal visual acuity and central vision mediated by the macula (Figure 1) [34,106-110]. Collectively, these carotenoids constitute the macular pigment, wherein they are uniquely concentrated within the axons of photoreceptor cells and the inner plexiform layer and outer plexiform layer of the foveal center in the macular region $[106,107,109,111,112]$. Obtained exclusively from dietary intake, lutein and zeaxanthin cannot be synthesized in the body $[107,113,114]$ and must be acquired from foods such as leafy green vegetables, corn, and egg yolks [107,110,113,114]. Mesozeaxanthin is a metabolite of lutein's transformation through RPE65 isomerase conversion in retinal pigment epithelium (RPE) [34,107,113,115-122]. Retinal uptake, metabolism, and transport mechanisms of xanthophyll carotenoids have been discussed in more detail elsewhere $[34,107,113,116,117,119,121-123]$. Depletion of these macular pigments, namely low macular pigment optical density (MPOD), may be associated with a significant increase in the risk of incident retinopathy and impaired visual function. 
<smiles>CC1=C[C@H](O)CC(C)(C)[C@H]1/C=C/C(C)=C/C=C/C(C)=C/C=C/C=C(C)/C=C/C=C(C)/C=C/C1=C(C)C[C@@H](C)CC1(C)C</smiles>

Lutein<smiles>CC1=C(/C=C/C(C)=C/C=C/C(C)=C/C=C/C=C(C)/C=C/C=C(C)/C=C/C2=C(C)C(C)(C)C[C@@H](O)C2)C(C)(C)CC(O)C1</smiles>

Zeaxanthin<smiles>CC(=O)OCCCCC=C(C)C=CC=CC(C)=CC=CC(C)=CC=CC(C)=CC=CC1=C(C)CC(O)CC1(C)C</smiles>

Figure 1. Chemical structures of the xanthophyll carotenoids lutein, zeaxanthin, and meso-zeaxanthin.

Dietary carotenoid supplementation may offer neuroprotection in the retina by augmenting the MPOD and subsequently delay the onset of glaucomatous pathology. The macular pigments are believed to protect the retinal tissue, in particular the photoreceptor cells located in the central region, through two primary mechanisms: (1) by acting as a filter against blue light; and (2) by limiting oxidative stress and inflammation induced by free radical species $[107,108,110,124-127]$. The peak wavelength of the MPOD absorption spectrum $(\sim 460 \mathrm{~nm})$ enables macular pigment to absorb a range of visible blue light (400-500 nm), thereby reducing the exposure of photoreceptors to blue light concomitant with improvements in visual performance $[106,126,128]$. The enhancement in optical filtration is particularly important because short-wavelength (blue) light is of high energy with significant potential to exacerbate photo-oxidative injury and ROS production in the highly susceptible layers of the outer retina [107,125-129]. Moreover, a growing body of evidence strongly indicates that higher MPOD levels afford enhanced retinal protection against the onset of neurodegeneration contributing to several ocular diseases, including glaucoma [107-110].

\subsection{Measuring $M P O D$}

Currently, several techniques are used to measure MPOD; they offer unique advantages as well as clinical limitations that have been discussed more thoroughly elsewhere $[34,109,110,130-135]$. In summary, non-invasive methods for quantifying levels of macular pigment include heterochromatic flicker photometry (HFP), customized HFP (cHFP), fundus reflectometry, and autofluorescence. The most commonly used are the psychophysical techniques HFP and cHFP [34,109,110,134-138], which rely on subjective perceptions to estimate the level of MPOD [139-141]. Conversely, the fundus reflectometry [142-147] and autofluorescence imaging (AFI) $[132,133,148,149]$ techniques rely on physical properties of the retina in order to collect measurements such as light reflectance and lipofuscin fluorescence, respectively $[34,110,130,131,134,150,151]$. It is important to note that validated measurements of MPOD levels can serve as susceptibility/risk biomarkers for the screening of early glaucomatous damage involving the macula [99], which may be clinically evident prior to central visual field loss on standard automated perimetry. 


\section{Materials and Methods}

This systematic review was conducted in accordance with the Preferred Reporting Items for Systemic reviews and Meta-Analysis (PRISMA) reporting guidelines [152].

\subsection{Literature Search}

A comprehensive literature review was conducted to identify published articles on the topic using database searches from PubMed, Web of Science, and the Cochrane Library indexes. We retrieved all relevant publications that reported findings on the association between glaucoma and MPOD/carotenoids (lutein and/or zeaxanthin and/or meso-zeaxanthin) from clinical and pre-clinical studies prior to 10 March 2021. The database search keywords used in the query included a combination of the following and their variants: carotenoids, lutein, zeaxanthin, macular pigment, macular pigment optical density, MPOD, antioxidants, glaucoma, open-angle glaucoma, and glaucomatous neurodegeneration. Initial publication results were screened for appropriate selection criteria and reviewed further based on titles and abstracts available in English. From the eligible publications, we manually performed both backward and forward searches from the reference lists and cited references to include all relevant literature, respectfully. Two authors (PGD and DWL) individually screened all eligible full-text studies for the inclusion/exclusion criteria outlined below, and any discrepancies were resolved by discussion including the third author (DLG).

\subsection{Selection Criteria}

Preclinical studies that satisfied the following criteria were included in this review: (1) evaluated the effect of carotenoid (lutein and/or zeaxanthin and/or meso-zeaxanthin) treatment on retinal cell survival, oxidative stress measures, or neurodegeneration-mediated outcomes in glaucoma-related injury, through cell culture studies of hypoxia/ischemia or experimental animal models of ischemia-reperfusion (by artificial IOP elevation or a cerebral artery occlusion model); (2) analyzed carotenoid treatment separately from other treatments/antioxidants in comparison with controls; and (3) used a methodology that was pertinent to glaucomatous-related injury in humans.

Observational clinical studies in this review were required to adhere to the following criteria: (1) studies evaluating the association between risk of open-angle glaucoma and carotenoid levels through dietary consumption of lutein and/or zeaxanthin or by validated clinical measurement of macular pigment optical density (MPOD) levels; (2) studies involving adults with confirmed presence of open-angle glaucoma or POAG; and (3) peer-reviewed original research.

Prospective randomized clinical trials that satisfied the following criteria were included in this review: (1) interventional studies assessing the effects of nutraceutical carotenoid supplement, containing lutein and zeaxanthin, on clinical endpoints in glaucoma patients; (2) studies that included human adults with the presence of open-angle glaucoma; and (3) peer-reviewed original research.

\subsection{Data Extraction and Reliability}

The PRISMA reporting guidelines were followed with care as closely as possible, as described previously [152].

\section{Results}

\subsection{Search and Selection of Studies}

In total, 426 studies were identified during the initial search from scientific databases. After duplicate records were removed and additional records were retrieved from reference lists, 352 studies remained for title and abstract screening. From these 352 studies, 198 records were excluded based on article type. Consequently, 118 records were excluded due to the aforementioned inclusion criteria for preclinical and clinical studies, and 34 studies were identified to be eligible for full-text assessment. Finally, 14 records were 
excluded because of the methodology used, with a resulting 20 studies included in the final review. Of the 20 studies analyzed, six were preclinical studies [46-51], eleven were observational clinical studies [54-59,153-157], and three were randomized controlled trials [60-62] (Figure 2).

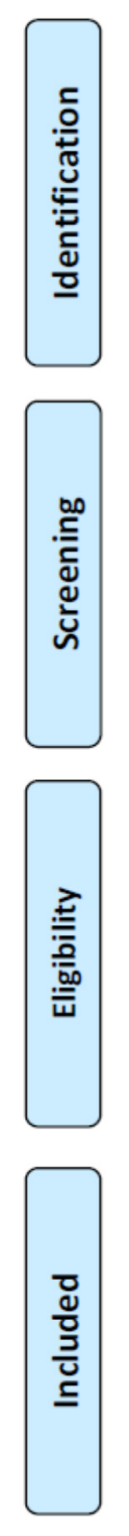

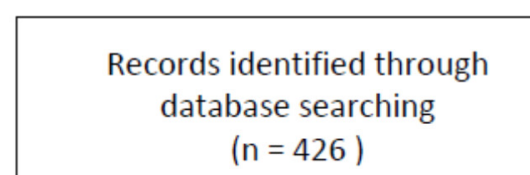

$(n=426)$

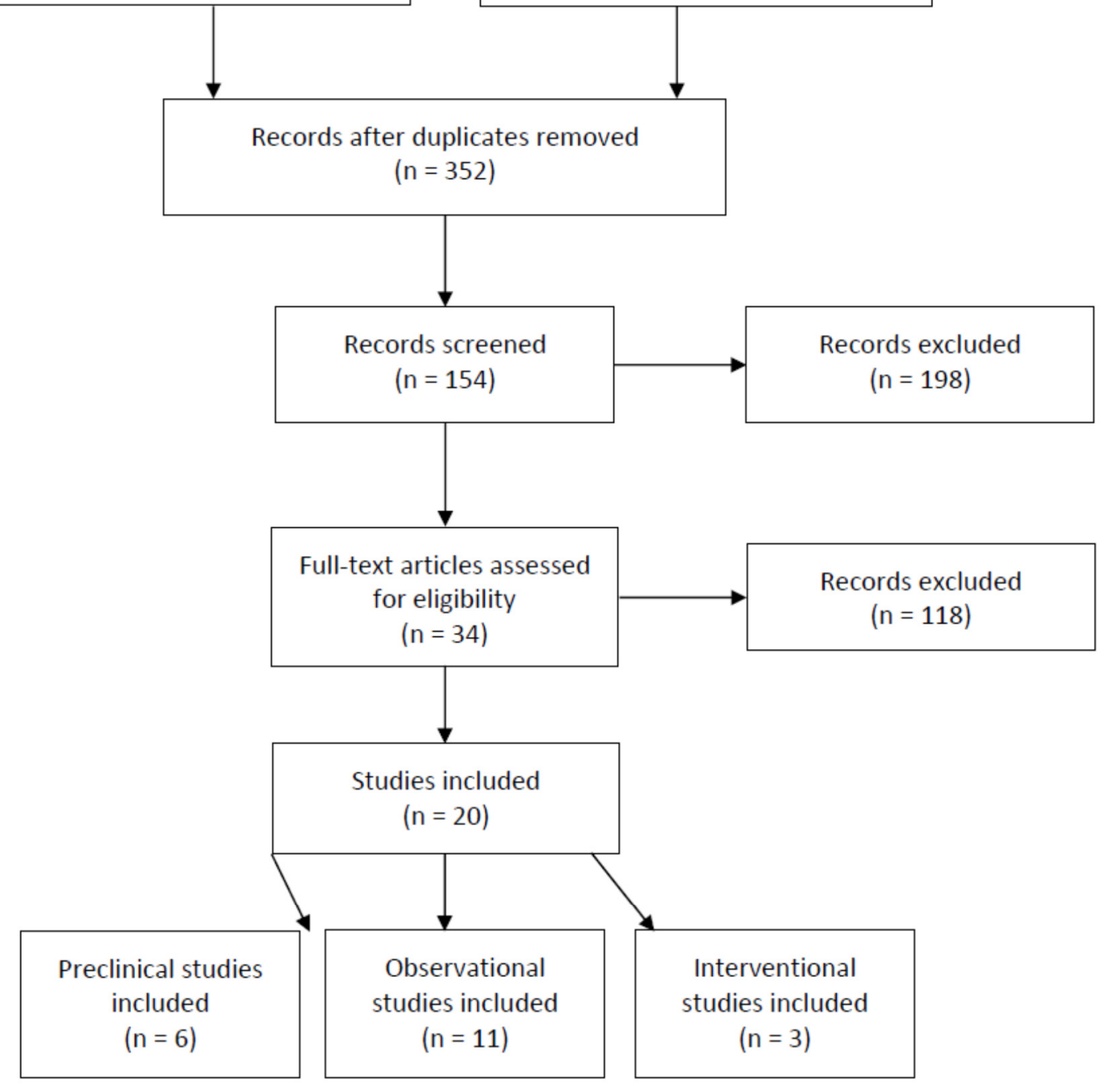

Figure 2. PRIMSA flow chart of the systematic review of publications on carotenoids in the management of glaucoma.

\subsection{Carotenoids in the Management of Glaucoma (Preclinical Studies)}

The therapeutic benefits of macular carotenoids have been documented in experimental models of glaucomatous pathology, investigating the molecular mechanisms underlying RGC loss; in particular, the protective effects of lutein and/or zeaxanthin on the progression of neurodegeneration in glaucoma (Table 1) [46-51]. Data from these reports are consistent with corroborating evidence that administration of the carotenoids lutein and zeaxanthin may provide substantial neuroprotective benefits in the retina by counteracting the causative factors that contribute to glaucomatous injury. Experimental models of glaucomatous neurodegeneration in vivo can be emulated in part by inducing retinal ischemia-reperfusion (I/R) via: (1) increasing IOP above systolic blood pressure by 
cannulation of the eye $[46,47,158-162]$; or (2) ligation of the internal carotid artery by an intraluminal method $[49,50,159,162-165]$. In rat Muller glial cells (rMC-1), in vitro hypoxic/ischemic conditions can be induced using cobalt (II) chloride $\left(\mathrm{CoCl}_{2}\right)$ to generate ROS/oxidative stress resulting in cell death $[48,50,166]$. Experimental murine models of RGC dysfunction/loss can be simulated by intravitreal injection of N-methyl-d-aspartic acid (NMDA) to mimic the in vivo glutamate excitotoxicity, which is triggered by ligand binding of NMDA receptors expressed by these ganglion cells in retinal neurons [51,167].

Table 1. Preclinical studies evaluating the effect of the carotenoids lutein and/or zeaxanthin on glaucomatous/RGC injury.

\begin{tabular}{|c|c|c|c|}
\hline Author, Year & $\begin{array}{l}\text { Glaucoma/RGC Injury } \\
\text { Model }\end{array}$ & Intervention & Main Findings \\
\hline Choi, 2006 [46] & $\begin{array}{l}\text { Retinal I/R injury by artificial } \\
\text { IOP elevation }\end{array}$ & Lutein & $\begin{array}{l}\text { Prevented an increase in nNOS and COX-2 } \\
\text { expression following ischemic injury }\end{array}$ \\
\hline Dilsiz, 2006 [47] & $\begin{array}{l}\text { Retinal I/R injury by artificial } \\
\text { IOP elevation }\end{array}$ & Lutein & $\begin{array}{l}\text { Reduced lipid peroxidation and activation of } \\
\text { caspase- } 3 \text { and improved GSH levels }\end{array}$ \\
\hline Fung, 2016 [48] & $\begin{array}{l}\text { Retinal I/R injury by } \\
\text { chemically induced hypoxia } \\
\text { in rMC- } 1 \text { cells }\end{array}$ & Lutein & $\begin{array}{l}\text { Improved glial cell survival and viability } \\
\text { following hypoxic injury through } \\
\text { modulating apoptosis and autophagy }\end{array}$ \\
\hline Li, 2009 [49] & $\begin{array}{l}\text { Retinal I/R injury by middle } \\
\text { cerebral artery occlusion }\end{array}$ & Lutein & $\begin{array}{l}\text { Enhanced ganglion cell survival, viability, } \\
\text { and morphology following I/R injury }\end{array}$ \\
\hline $\mathrm{Li}, 2012$ [50] & $\begin{array}{l}\text { Retinal I/R injury by middle } \\
\text { cerebral artery occlusion and } \\
\text { chemically induced hypoxia } \\
\text { in rMC-1 cells }\end{array}$ & Lutein & $\begin{array}{l}\text { Improved measures of retinal function, with } \\
\text { reduced gliosis and increased cell survival }\end{array}$ \\
\hline Zhang, 2016 [51] & $\begin{array}{l}\text { RGC injury by intravitreal } \\
\text { NMDA injection }\end{array}$ & Lutein & $\begin{array}{l}\text { Augmented ganglion cell viability with } \\
\text { improved retinal function parameters }\end{array}$ \\
\hline
\end{tabular}

Abbreviations: RGC, retinal ganglion cells; I/R, ischemia-reperfusion; IOP, intraocular pressure; nNOS, neuronal nitric oxide synthase; COX-2, cyclooxygenase-2; GSH, glutathione; rMC-1, rat Muller glial cells; NMDA, N-methyl-d-aspartic acid.

Experimental models of glaucomatous neurodegeneration implicate oxidative stress among the primary mechanisms in early ischemic retinal injury, caused by overwhelming production of pro-oxidant stressors and a compromised antioxidant capacity. It is known that the retina is highly susceptible to free radical formation partly because of its extremely high metabolic activity and abundance of polyunsaturated fatty acids concentrated in the outer segment of photoreceptor cells [26-28]. In murine models of acute I/R, lutein's neuroprotective effect was seen to successfully prevent against measures of both oxidative and nitrosative stress that have been attributed to glaucomatous neurodegeneration $[46,47,49]$. Carotenoids may protect the inner retina by actively neutralizing free radicals and concomitantly protecting against subsequent oxidative injury, such as lipid peroxidation and oxidative DNA damage [168,169]. Indeed, treatment with lutein effectively prevented increases in malondialdehyde [47] and polymeric adenosine diphosphate ribose (PAR) [49] induced by I/R injury, respectively. Lutein has also been observed to be neuroprotective against nitrosative stress in ischemic retina by reducing NOS activation and thereby limiting the subsequent overexpression of nitric oxide (NO), both of which are recognized to contribute significantly to neurodegeneration $[46,49,170,171]$. Evidence from murine models seems to mirror these findings, where it was observed that lutein can successfully diminish nitrosative injury as evidenced by reduced expression levels of neuronal NOS [46] and nitrotyrosine [49], a footprint indicator of protein oxidation by reactive nitrogen species [70,170,172]. The anti-oxidative capacity of macular carotenoids, particularly in ischemic retina, is important because both vascular and biomechanical theories of glaucoma attribute IOP-related injury to the ONH and progressive loss of RGCs exacerbated by oxidative stress $[28,78,173,174]$.

Thus, a retinal imbalance between the overwhelming generation of pro-oxidant stressors and a compromised antioxidant capacity has been posited, among several mechanisms, 
to be an important causative agent of glaucomatous RGC loss. In humans, there is evidence of an intracellular redox imbalance whereby endogenous antioxidant defenses are compromised in consequence of uncontrolled oxidative stress $[175,176]$. However, there is a paucity of preclinical research investigating the antioxidant capacity in experimental models of glaucomatous-related injury [47]. In fact, only one study evaluated lutein treatment on concentrations of the endogenous antioxidant GSH in rat retina following I/R by artificial IOP elevation [47]. Administration of lutein was effective against depletion of GSH induced by ischemic injury and restored GSH to levels similar to those observed in healthy control animals. Alternatively, evidence from murine models of diabetic retinopathy helps to corroborate the synergic neuroprotective effect of carotenoid treatment (including lutein and/or zeaxanthin) on limiting oxidative stress while simultaneously augmenting endogenous antioxidant defenses [177-179].

Macular carotenoids may protect against glaucomatous injury indirectly by inhibiting pro-inflammatory pathways triggered by aberrant free radical production and oxidative insult contributing to chronic low-grade inflammation [50,180-183]. Lutein's potent antiinflammatory effects have been demonstrated to protect against post-ischemic injury via modulating activation of the nuclear transcription factor nuclear factor kappa B (NF-kB), a vital redox-sensitive transcriptional regulator of pro-inflammatory cytokines and secondary inflammatory markers expressed during the innate immune response [50,184-191]. Additionally, lutein treatment was also observed to suppress retinal expression of COX2 [46,50] and interleukin-1 $\beta[50,192]$. The former is a stress response gene [190] and the latter triggers the NF-kB canonical inflammatory response pathway upon cytokine receptor activation $[189,191,193]$. Similarly, treatment with lutein produced a marked decrease in Muller cell gliosis [50], a significant source of pro-inflammatory cytokine production $[48,80,194,195]$. In ischemic retinal injury, significant attenuation of Muller cell hypertrophy and glial fibrillary acidic protein activation were achieved following treatment with lutein [50]. Interestingly, these findings suggest that the neuroprotective mechanism may involve the adaptive injury response facilitated by reciprocal cell signaling between Muller cells and microglia during post-injury inflammation; in fact, activation of microglia and activation of macroglia (i.e., Muller cells and astrocytes) are among the initial steps in the neurodegenerative onset that precedes RGC loss in humans [196-200]. Thus, the retinal benefits of lutein may limit the propagation of immune response pathways to suppress neuroinflammation and, in effect, preserve the inner retina against subsequent RGC loss and apoptotic degeneration.

The cumulative effect of glaucoma is progressive neurodegeneration of the inner retina and RGC loss by apoptotic mechanisms [72,201,202]. In experimental models of retinal injury by artificial IOP elevation $[161,203]$ and an intraluminal method $[49,50,204]$, significant cell loss was observed in the ganglion cell layer (GCL) and the inner nuclear layer (INL) as evidenced by loosely packed cells and condensation of nuclear chromatin. Following treatment with lutein, inner layers of mouse retina were seen to have densely packed cells and a marked reduction in pyknotic nuclei, indicating a normal morphology following ischemic injury $[49,50]$. Lutein-mediated protection of inner retinal cells may in part be explained by improvements observed in cell viability [48-51] and cell survival [46,48] upon glaucomatous injury. Administration of lutein was shown to increase cell survival in both the GCL and the INL of ischemic rat retina by IOP elevation [46] and enhance the survival of Muller glia after $\mathrm{CoCl}_{2}$-induced hypoxia [48]. Experimental findings suggest that lutein may protect the retinal tissue by augmenting cell survival concomitant with protecting against glaucomatous cell death induced by an apoptotic mechanism. Indeed, administration of lutein significantly reduced the presence of apoptotic nuclei in Muller glia upon a terminal deoxynucleotidyl transferase dUTP nick end labeling (TUNEL) assay following hypoxic injury by chemical induction [48]. Improvements were also observed in the GCL and the INL of mouse retina following intraluminal I/R injury [49], providing supplementary evidence that lutein may successfully protect against apoptotic neurodegeneration in the inner retina. Thus, preliminary findings indicate that the neuroprotective potential of 
lutein in maintaining the retina, an integral component of the central nervous system, is essential to preventing irreversible neural degeneration and subsequent vision loss.

Lutein may protect the inner retina against glaucomatous neurodegeneration by inhibiting pro-apoptotic pathways induced by hypoxic/ischemic injury. In fact, the antiapoptotic potential of lutein has been documented in a variety of in vivo and in vitro experimental models of retinopathies characterized by neurodegeneration [48,50,52,182,205-207]. One study in Muller glia cells suggests that the possible mechanistic pathway of lutein's protection involves suppression of the intrinsic mitochondrial pathway after simulated hypoxic challenge [48]. Lutein treatment effectively suppressed activation of the intrinsic apoptosis induced by hypoxic injury [208,209], as evidenced by increased expression of the pro-survival protein $\mathrm{B}$ cell lymphoma $2(\mathrm{Bcl}-2)$ and a reduced expression ratio of the $\mathrm{Bax} / \mathrm{Bcl}-2$ proteins [48], a key determinant in apoptosis triggered by mitochondrial dysfunction [30,210-214]. Importantly, lutein successfully reduced cleavage of caspase-3 [48], effectively limiting activation of the executioner caspase and supporting lutein-mediated neuroprotection through caspase-associated modulation [30,210-212,214,215]. Results in an animal model of ischemic injury mirrored these findings, where it was observed that lutein had a significant ameliorative effect on caspase- 3 activation induced by elevated IOP in rat retina [47]. Lutein's reducing of ischemic apoptosis is important because bidirectional signaling between microglia and Muller cells in response to injury $[196,197]$ can exacerbate neurotoxic effects by enhancing oxidative stressors and further spreading neuroinflammatory processes via cytokine signaling [216-220].

Carotenoids have also been shown to be neuroprotective in maintaining synaptic activity. One school of thought suggests that the protective mechanism of carotenoids involves limiting trans-synaptic degeneration. That is, carotenoids limit secondary degeneration to neurons that follows remote neuronal injury, by supplying significant synaptic activity and, thereby, decreasing retinal apoptosis [53,71,102]. Purported mechanisms underlying cell death in RGCs are hypothesized to involve excitotoxicity resulting from aberrant glutamate receptor activation [221-226] or neurotrophic signaling deprivation caused by deficits in axonal transport [227-229]. One study found that lutein treatment significantly enhanced RGC viability in rat retina following NMDA-induced neurotoxicity [51]. In fact, a Western blot analysis of mitochondrial apoptotic proteins mirrored these findings, indicating that lutein rescued RGC viability by augmenting retinal expression of the pro-survival protein Bcl-2 while inhibiting the expression of Bax, cleaved caspase-3, and cytochrome c [51]. Lutein supplementation may enhance RGC survival in part by improving the axoplasmic flow of neurotrophins between the ganglion cell body and its distal synapse located deep in the brain $[53,230]$; in fact, lutein was seen to increase retrograde transport of brain-derived neuronal trophic factor (BDNF) in a murine model of diabetic neurodegeneration [205]. Based on observations made in experimental models, it has been hypothesized that the primary site of axonal transport dysregulation is the lamina cribrosa and it may be triggered by biomechanical stress/damage to the ONH and RNFL [53,227,230-232]. Thus, the benefits of lutein treatment observed in experimental models of glaucomatous neurodegeneration may in part be explained by augmentation of RGC survival and thereby preservation of synaptic network activity within retinogeniculate axons that relay visual information to the visual cortex $[53,69,71]$.

Visual dysfunction caused by retinal degeneration, measured noninvasively by electroretinogram (ERG), showed an obvious reduction in the ERG response generated at the post-receptor level of the inner retina [50,51]. In a rodent model of ischemic glaucomatous injury, a functional impairment was indicated by a significantly smaller oscillatory potential amplitude and b-wave/a-wave ratio [50], the latter being a sensitive prognostic measure of ischemic injury in both animal models and humans [233-236]. Similar results were seen in NMDA-induced RGC injury, showing a significant reduction in the amplitude of the photopic negative response, which implied a post-receptor impairment [51]. However, treatment with lutein successfully restored the retinal function on ERG in both models of glaucomatous injury believed to contribute to optic neuropathy in POAG $[50,51]$. Ad- 
ditionally, lutein markedly enhanced visual function in vivo in excitotoxic-induced RGC injury, as shown by significant improvements in white-black discrimination during a visual behavior assay [51]. These findings provide further support to macular carotenoids' nutraceutical effect in maintaining visual function against neurodegenerative insult.

However, it is worth noting that findings from in vitro studies evaluating the effect of supplementation with lutein and/or zeaxanthin using the disputed RGC-5 cell line [237-239] have been purposefully omitted from this review [240,241]. The original publication has since been redacted for erroneously characterizing the RGC- 5 cell line to be of rat retinal ganglion origin $[237,239]$. It is now known to correspond to the mouse cell line $661 \mathrm{~W}$, which has been confirmed to be of cone photoreceptor origin [238,239,242-244].

While results from experimental models of glaucomatous injury indicate that the carotenoids lutein and/or zeaxanthin are sufficiently neuroprotective against neurodegeneration in the inner retina, there are some limitations to these findings that must be reviewed. Briefly, the absence of studies on the effects of carotenoid treatment in nonmurine models restricts the translative potential for clinical use due to species differences between humans and rodents; specifically, the absence of the macula in these animals [245]. Further, the limited sample size may result from the complex nature of glaucoma as a multifactorial disease. This becomes clear as experimental models of glaucomatous RGC loss induced by transient ischemia-reperfusion through artificial IOP elevation [46,47], internal carotid artery occlusion $[49,50]$, or chemically induced hypoxia $[48,50]$ are incomplete models of the etiopathogenesis of glaucoma in humans [245]. Only one study evaluated the protective effects of lutein in a model of RGC injury induced by intravitreal NMDA injection [51]. However, one may conclude that there is substantial evidence in support of the anti-oxidative, anti-inflammatory, and pro-survival capacity of the carotenoids lutein and zeaxanthin in protecting against retinal neurodegeneration.

\subsection{Carotenoids in the Managament of Glaucoma (Clinical Studies)}

A growing body of evidence strongly suggests that a reduction in antioxidants resulting from prolonged oxidative stress is an essential driver in the initial sequence of interconnected mechanisms that contribute to the glaucomatous pathogenesis [23-25]. In the aqueous humor of patients with POAG, reports consistently demonstrate a significant reduction in total antioxidant capacity when compared with age-matched healthy controls [246-248]. One school of thought suggests that this response may be the longstanding consequence of protective mechanisms in the retina involving endogenous antioxidant defenses attempting to maintain redox homeostasis and limit oxidative injury by neutralizing pro-oxidant stressors $[76,248,249]$. Indeed, enhanced enzymatic activity of the potent antioxidants glutathione peroxidase and superoxide dismutase is seen in the glaucomatous eye $[76,250,251]$ concomitantly with overexpressed markers of oxidation products (e.g., malondialdehyde) in the serum and aqueous humor $[246,247,252,253]$. Data from a metaanalysis corroborate these findings, providing consistent evidence of a systemic imbalance between oxidative stress and antioxidant levels in various types of glaucomatous injury, including but not limited to POAG [253]. However, cross-sectional studies indicate that the reduction in serum antioxidant status may be more profound in patients with open-angle glaucoma in comparison with closed-angle or pseudoexfoliation types [175]. Thus, it is clear that diminution of the endogenous antioxidant capacity, in response to persistent oxidative stressors in glaucomatous eyes, is an important pathogenetic mechanism in the occurrence and progression of POAG.

\subsection{Dietary L/Z Intake and Risk of Glaucoma-Epidemiology Studies}

To date, a number of epidemiological studies have evaluated the potential association between dietary carotenoid consumption (i.e., lutein and zeaxanthin, L/Z) and incident glaucoma, largely with inconsistent results [153-157]. From data collected by two largescale prospective cohorts totaling over 100,000 participants, pooled multivariate analyses from the Nurses' Health Study (NHS) and the Health Professionals Follow-up Study (HPFS) 
found that increased dietary levels of $\mathrm{L} / \mathrm{Z}$ were the only serum antioxidants with material relevance to incident glaucoma [155]. Adjusting for the putative time delay from the etiologically relevant intake/exposure until the date of clinical diagnosis (i.e., a four-year lagged analysis), researchers found that individuals in the highest quintile of $\mathrm{L} / \mathrm{Z}$ consumption had a significantly reduced risk for prevalent POAG than those in the lowest quintile (rate ratio $(\mathrm{RR})=0.68,95 \%$ confidence interval $(\mathrm{CI}): 0.49-0.93)$ [155]. Conversely, a univariate analysis of antioxidant equivalents from a population-based cohort aged 55 years and older in the Rotterdam Study found no protective association between $\mathrm{L} / \mathrm{Z}$ consumption and risk for open-angle glaucoma [157]. Despite this, an updated report from the NHS and HPFS found a $20 \%$ reduction in POAG incidence among individuals with higher daily servings of food groups rich in $\mathrm{L} / \mathrm{Z}$ content $(\mathrm{RR}=0.82,95 \% \mathrm{CI}$ : 0.69-0.97), more specifically green leafy vegetables such as kale, lettuce, and cooked/raw spinach [156,254,255]. However, these findings were suggested to largely be attributed to the greater intake of dietary nitrates derived from vegetable consumption [156,256,257]. After adjusting for dietary carotenoids and additional nutrients, a similar inverse association was seen between dietary nitrate consumption and risk of POAG $(\mathrm{RR}=0.67,95 \% \mathrm{CI}$ : 0.52-0.85), which retained statistical significance [156]. Nonetheless, it remains unclear whether these effects are truly independent of the strongly associated nutrient content of lutein and zeaxanthin obtained simultaneously from these leafy green vegetable food groups.

Despite the preliminary evidence from large-scale cohort studies being inconsistent in substantiating a relationship between dietary carotenoids and glaucoma, evidence from other groups seems to corroborate a protective association with greater consumption of food groups rich in L/Z content $[153,154]$. One school of thought suggests that higher intake of $\mathrm{L} / \mathrm{Z}$ may serve to improve the retinal vasculature's caliber and protect against signs of vascular dysregulation [258]. Established risk factors of cardiovascular disease are strongly associated with glaucomatous RNFL atrophy and POAG incidence [256,259-261]. A crosssectional analysis from one report in the Study of Osteoporotic Fractures found a significant protective association among women aged 65 and older who consumed $\geq 1$ serving of collard greens and kale per month (odds ratio $(\mathrm{OR})=0.31,95 \% \mathrm{CI}$ : 0.11-0.91) [153]. Several common leafy green vegetables, including kale and collard greens, from the cabbage species Brassica oleracea are major dietary sources of L/Z [123,254,262,263]. More recently, a cross-sectional analysis from a cohort of African-American women included in the Study of Osteoporotic Fractures found a more significant protective trend against incident glaucoma among women consuming more collard greens/kale on a weekly basis ( $\geq 1$ serving per week; OR $=0.43,95 \%$ CI: 0.21-0.85) [154]. In fact, after adjusting for potential confounders, researchers found that African-American women in the highest quartile of daily $\mathrm{L} / \mathrm{Z}$ intake ( $\geq 4000 \mu \mathrm{g} /$ day) were strongly associated with a significant reduction in the odds of glaucoma (OR $=0.43,95 \% \mathrm{CI}$ : 0.21-0.88) [154]. Moreover, these results may be attributable, at least in part, to an increase in daily servings of $L / Z$, which seem to reflect a protective trend in retinal vasculature against glaucomatous etiology.

The evidence from epidemiological studies investigating the association between dietary L/Z intake and risk of incident glaucoma is promising, but not without certain limitations [153-157]. An inherent challenge in studying glaucoma prevalence in large-scale nutritional epidemiology remains the insidious nature of this neurodegenerative optic neuropathy $[78,153,154,264]$. Hence, the etiologically relevant time period/exposure likely involves dietary behaviors that occurred several years prior to the date of diagnosis in consequence of clinical signs becoming apparent only after substantial damage is incurred to the ONH $[78,264]$. Variation among the inclusion criteria for the presence of glaucoma in large-cohort studies, relying largely on self-reported cases, may limit the interpretability of these results for the general population [155-157]. Meanwhile, cross-sectional cohorts were ascertained by optic nerve imaging and VF assessment during a clinical eye examination $[153,154]$. None of the aforementioned epidemiology studies directly investigated the association between serum levels of carotenoids and risk of POAG. However, the protective 
trends demonstrated herein provide support to greater dietary intake of the carotenoids $\mathrm{L} / \mathrm{Z}$ among older individuals and those at risk of ocular diseases, including glaucoma.

\subsection{Macular Pigment Optical Density and Primary Open-Angle Glaucoma}

The neuroprotective potential of macular pigment concentrations of $\mathrm{L} / \mathrm{Z}$ in the pathogenesis of glaucomatous optic neuropathy have been explored in a limited number of studies. To date, there have been six clinical studies that explicitly measured MPOD levels in glaucomatous eyes to determine the relationship between macular pigment status and the presence of POAG [54-59]. Although some discrepancies exist among reports, the evidence generally suggests that MPOD levels are significantly reduced in glaucomatous eyes and may be further compromised with greater disease severity [56-59]. Similarly, there is a need to substantiate the structure-function relationship between macular ganglion cell thinning and the extent of functional visual loss associated with glaucoma [265-267]. A summary of clinical studies in relation to the putative association between MPOD and clinical parameters of POAG is given in Table 2.

Table 2. Clinical studies evaluating macular pigment optical density (MPOD) in open-angle glaucoma.

\begin{tabular}{|c|c|c|c|c|}
\hline Author (Year) & Participants & $\begin{array}{l}\text { MPOD Measurement } \\
\text { Technique }\end{array}$ & Exposure Variable & Main Findings \\
\hline Bruns (2020) [54] & $\begin{array}{c}33 \text { POAG cases } \\
43 \text { healthy controls }\end{array}$ & Dual-wavelength AFI & $0.51^{\circ}, 1.02^{\circ}$, and $1.99^{\circ}$ & $\begin{array}{l}\text { No evidence of lower MPOD } \\
\text { in glaucomatous eyes }\end{array}$ \\
\hline Daga (2018) [55] & $\begin{array}{c}85 \text { POAG cases } \\
22 \text { healthy controls }\end{array}$ & Dual-wavelength AFI & MP volume over $7^{\circ}$ & $\begin{array}{l}\text { MP volume was comparable } \\
\text { between glaucomatous eyes } \\
\text { and controls }\end{array}$ \\
\hline Igras (2013) [56] & $\begin{array}{l}36 \text { POAG cases } \\
54 \text { healthy controls }\end{array}$ & HFP & $0.5^{\circ}$ & $\begin{array}{l}\text { Lower MPOD in glaucomatous } \\
\text { eyes compared with controls } \\
\qquad(p=0.03)\end{array}$ \\
\hline Ji (2016) [57] & $\begin{array}{c}30 \text { POAG cases } \\
52 \text { healthy controls }\end{array}$ & $\begin{array}{l}\text { Single-wavelength } \\
\text { Reflectometry }\end{array}$ & MPOD mean over $7^{\circ}$ & $\begin{array}{l}\text { Significantly reduced MPOD } \\
\text { and GCC thickness in POAG } \\
\text { patients }(p<0.001 \text {, for all })\end{array}$ \\
\hline Siah (2015) [58] & $\begin{array}{l}44 \text { POAG cases } \\
\text { (22 with foveal } \\
\text { involvement) }\end{array}$ & cHFP & $0.25^{\circ}, 0.5^{\circ}$, and $1^{\circ}$ & $\begin{array}{c}\text { Glaucomatous eyes with } \\
\text { foveal GCC loss had a lower } \\
\text { overall MPOD } \\
(p<0.001 \text {, for all })\end{array}$ \\
\hline Siah (2018) [59] & 88 OAG cases & cHFP & $0.25^{\circ}, 0.5^{\circ}$, and $1^{\circ}$ & $\begin{array}{l}\text { Lower MPOD was correlated } \\
\text { with the magnitude of the } \\
\text { central } 10^{\circ} \text { field loss }(p<0.01 \text {, } \\
\text { for all })\end{array}$ \\
\hline
\end{tabular}

Abbreviations: MPOD, macular pigment optical density; POAG, primary open-angle glaucoma; AFI, autofluorescence imaging; MP, macular pigment; HFP, heterochromatic flicker photometry; GCC, ganglion cell complex; cHFP, customized heterochromatic flicker photometry; OAG, open-angle glaucoma.

Glaucomatous neurodegeneration is multifaceted and has a complex etiopathogenesis, so it is not surprising that there are differing schools of thought regarding possible causative mechanisms whereby the MPOD may be lower in patients with POAG. Several prospective studies found significant reductions in the spatial profile of macular pigments within $1^{\circ}$ of retinal eccentricity in glaucomatous eyes using a customized HFP (cHFP) technique $[56,58,59]$. Similarly, the MPOD was also significantly reduced in a cohort of Chinese patients with POAG $(p<0.001)$ as compared with age-matched controls and measured by single-wavelength reflectometry [57]. Researchers suggest that reductions in MPOD may be explained, in part, by apoptosis of RGCs and neurodegeneration of the nerve fiber layer as concomitants of the pro-oxidative environment in glaucomatous retina. Thus, the loss of photoreceptors and ganglion cells may severely compromise the localization of macular pigment within the innermost retinal layers of the fovea $[59,264,268,269]$. In 
fact, cross-sectional studies observed, upon FD-OCT imaging of the retina, that the MPOD was significantly lower in those who exhibited structural thinning of the ganglion cell complex (GCC) that encroaches upon the foveal zone [58,59]. Data from these studies determined that the presence of foveal GCC loss was a major determinant of MPOD levels in glaucomatous eyes [58,59]. Similar results from a case-control study mirrored these findings, demonstrating that both the maximum and mean MPOD levels displayed a positive relationship with macular GCC thickness on SD-OCT $(p<0.001$ and $p=0.001$, respectively) [57]. Glaucomatous eyes with foveal GCC loss also exhibited greater disease severity, as evidenced by thinning of the RNFL and the GCC layer, an increased cup-to-disc ratio, or narrowing of the neuroretinal $\operatorname{rim}(p<0.001$, for all) [58]. This is of relevance because early glaucomatous injury to retinal substructures likely involves the macula, in particular the layers that comprise the GCC [99,267]; that is, the nerve fiber layer, the ganglion cell layer, and the inner plexiform layer, which correspond to the axons, cell bodies, and dendrites of retinal ganglion cells, respectively. Thus, given that glaucoma appears to target the retinal layers in which macular pigment is primarily localized, this may explain, at least in part, the finding that the MPOD appears to be lower in more severe cases of POAG with foveal involvement.

Macular involvement with corresponding VF defects in early stages of glaucoma may be more common than previously realized, as evidenced by paracentral scotoma on standard automated perimetry $[270,271]$. Thus, glaucomatous loss of foveal RGCs with a subsequent MPOD decrease is likely to be of significance in relation to vision-related quality of life for patients with POAG. The literature provides a strong rationale to support a structure-function relationship between a greater reduction in MPOD with foveal ganglion cell loss and corresponding VF defects in glaucoma $[37,57-59,99,270]$. A cross-sectional analysis found that functional vision loss in the central retina (within $10^{\circ}$ of fixation) was significantly correlated with a lower MPOD at multiple retinal eccentricities among those with foveal GCC involvement $\left(p<0.01\right.$ at $0.25^{\circ}, 0.5^{\circ} ; p=0.01$ at $\left.1^{\circ}\right)$ [59]. Glaucomatous foveal scotoma was assessed by mean deviation (MD) on the Humphrey 10-2 VF test because it samples macular visual function more precisely than the standard 24-2 VF test $[59,272-275]$. Furthermore, not only were lower MPOD levels associated with greater glare-related disability and reduced glare-related visual performance in the glaucomatous eye, but it appeared that this relationship was mediated by foveal involvement [59]. Given that the macula contains the highest density of RGCs ( 50\% concentrated within $4.5 \mathrm{~mm}$ of the fovea) [34,276], observations in which foveal involvement relates to a lower MPOD, as encountered in glaucoma, may therefore elucidate, at least in part, the degree of functional vision loss in cases of POAG.

On the other hand, two prospective studies were unable to demonstrate a significant correlation between macular pigment and the presence of POAG using dual-wavelength autofluorescence imaging [54,55]. In the first study, a cross-sectional analysis found that macular pigment volumes were comparable between glaucomatous eyes and controls [55]. Similarly, a case-control study found no significant evidence that the MPOD was lower in glaucoma patients, or that a lower MPOD was linked to the presence of glare symptoms [54]. The inconsistency in results may be attributed, at least in part, to differences in the study methodology with regard to the MPOD measurement technique [132-134]. Briefly, because the cHFP technique is psychophysical in nature, it cannot be ruled out whether the presence of glaucoma may have influenced the individual's fixation capacity and affected the acquisition of MPOD measurements. Despite this, cHFP remains the current gold standard approach to MPOD measurement in clinical applications.

The results from these [54-59] clinical studies that have investigated the relationship between MPOD and glaucomatous neurodegeneration are promising, but not without several limitations: (1) with one exception [57], the inclusion criteria for the presence of glaucoma were not exclusive to individuals with POAG; (2) with one exception [58], foveal involvement was analyzed homogenously among different subtypes of open-angle glaucoma in relation to MPOD levels; (3) there were relatively small and unequal sample sizes 
based on ocular health status (glaucoma vs control) in several studies; and (4) all studies were observational in nature only. Additional research is necessary to further investigate the potential relationship whereby the MPOD appears to be lower in glaucomatous eyes and may be further compromised among those with greater disease severity.

\subsection{Carotenoid Supplementation-Interventional Studies}

Prospective studies in patients with glaucoma evaluating the efficacy of dietary carotenoid supplementation with antioxidant micronutrient formulas in randomized controlled trials (RCTs) remain limited and controversial at best (Table 3) [60-62]. In an openlabel long-term follow up assignment among patients with mild/moderate POAG, two experimental antioxidant formulas containing lutein $(6 \mathrm{mg})$ and zeaxanthin $(0.3-0.5 \mathrm{mg})$, with or without omega-3 fatty acids, failed to demonstrate any difference between groups at the end of trial period [60]. Researchers found no significant change with either supplement after a two-year follow up on visual field loss or quantitative measures indicating thinning of the RNFL or the GCC upon FD-OCT scanning [60]. In contrast, a prospective study with an antioxidant nutraceutical formula containing lutein $(10 \mathrm{mg})$ and zeaxanthin $(2 \mathrm{mg})$ in equal groups of healthy controls and POAG patients found a significant protective trend with carotenoid supplementation after a six-month follow up [62]. In the POAG group, a marked increase in plasma antioxidant capacity $(p=0.028)$, with a concomitant reduction in the pro-oxidant stressor malondialdehyde, reached greater significance $(p=0.005)$ [62]. Similar protective trends have also been observed in clinical trials with a carotenoid supplement nutraceutical conducted in patients with pseudoexfoliative glaucoma [61]. However, there is simply a paucity of evidence from clinical trials to sufficiently determine the precise neuroprotective potential in open-angle glaucomatous injury. Hence, further interventional studies are required should carotenoid vitamin therapy be immediately considered a primary form of treatment in the management of glaucomatous neurodegeneration.

Table 3. Characteristics of the eligible randomized clinical trials.

\begin{tabular}{|c|c|c|c|c|c|}
\hline Author (Year) & Participants & Duration & $\begin{array}{l}\text { No. of } \\
\text { Groups }\end{array}$ & Interventions & $\begin{array}{l}\text { Treatment } \\
\text { Schedule }\end{array}$ \\
\hline $\begin{array}{l}\text { Garcia-Medina } \\
\text { (2015) [60] }\end{array}$ & $\begin{array}{l}117 \text { patients with } \\
\text { mild/moderate POAG, } \\
\text { aged }(61.5 \pm 11.7) \text { years }\end{array}$ & 2 years & 3 & $\begin{array}{c}6 \mathrm{mg} \mathrm{L} \text { and } 0.3 \mathrm{mg} \mathrm{Z} \\
\text { (multivitamin plus } \omega-3 \text { ); } 6 \mathrm{mg} \mathrm{L} \\
\text { and } 0.5 \mathrm{mg} \mathrm{Z} \mathrm{(multivitamin} \\
\text { only); placebo }\end{array}$ & 5 days $/ w k$ \\
\hline $\begin{array}{l}\text { Romeo Villadóniga } \\
\text { (2018) [61] }\end{array}$ & $\begin{array}{l}47 \text { patients with PEX, } \\
\text { aged }(70.3 \pm 5.0) \text { years }\end{array}$ & 6 months & 2 & $\begin{array}{c}10 \mathrm{mg} \mathrm{L} \text { and } 1 \mathrm{mg} \mathrm{Z} \\
\text { (multivitamin); placebo }\end{array}$ & Daily \\
\hline $\begin{array}{l}\text { Sanz-González } \\
\text { (2020) [62] }\end{array}$ & $\begin{array}{c}15 \text { patients with POAG } \\
\text { and } 15 \text { controls, aged } \\
40-75 \text { years }\end{array}$ & 6 months & 2 & $\begin{array}{l}10 \mathrm{mg} \mathrm{L} \text { and } 2 \mathrm{mg} \mathrm{Z} \\
\text { (multivitamin) }\end{array}$ & Daily \\
\hline
\end{tabular}

Abbreviations: POAG, primary open-angle glaucoma; L, lutein; Z, zeaxanthin; $\omega$-3, omega-3 fatty acids; PEX, pseudoexfoliative glaucoma.

Inconsistency among findings from these intervention trials may be attributed, at least in part, to a variety of potential factors and limitations. Most notably, none of the available trials included a serum analysis of lutein and zeaxanthin or measured MPOD levels within the study design. Limitations regarding low absorption rates continue to pose a major challenge to clinical trials $[277,278]$. A growing body of evidence strongly suggests that conventional delivery systems, such as the soft-gel capsules used within all three reports, may significantly limit the bioavailability of carotenoids and consequently impede the desired health benefits in the retina [43,122,277-280]. To overcome such a limitation, greater amounts of carotenoids may be necessary along with a longer duration of intake. Assimilation and transport of carotenoids from food matrices are also heavily influenced by anthropometric features as well as gender, ethnicity, and age $[45,116,279,281-286]$. Enhanced performance in the bioavailability and accumulation of lutein and zeaxanthin in the retina has been demonstrated using micronized and nanoemulsion-based microsphere tech- 
niques [43,278,286-289]. Moreover, clinical implementation of these carotenoid-containing microspheres has shown improved dissolution efficacy while maintaining overall safety when applied intraocularly.

\section{Conclusions}

There is a theoretical rationale for the use of carotenoid vitamin therapy as an adjunctive treatment in the management of glaucoma. It appears that the glaucomatous retina creates an environment hostile to the survival of neurons, in part due to sustained oxidative injury with a concomitant depletion of endogenous antioxidant defenses. The cumulative effect of glaucoma appears to compromise the localization of the macular carotenoids lutein, zeaxanthin, and meso-zeaxanthin, contributing to deteriorating retinal health and ultimately irreversible vision loss. Based on the available preliminary results, carotenoid vitamin therapy has shown promise in augmenting MPOD levels and enhancing visual performance. In this regard, there is sufficient evidence from preclinical studies to support the synergic neuroprotective benefits of carotenoid supplementation as an adjunctive nutraceutical approach to the management of glaucoma. However, the available results from clinical trials are largely controversial and insufficient at present, thereby warranting further prospective controlled studies. Thus, it remains to be seen if this adjunctive nutraceutical approach, in combination with IOP-lowering therapy, can provide additional protective benefits to glaucomatous eyes.

Author Contributions: Conceptualization, D.W.L. and P.G.D.; methodology, D.W.L. and P.G.D.; data curation, D.W.L.; writing-original draft preparation, D.W.L. and P.G.D.; writing-review and editing, D.W.L., D.L.G. and P.G.D. All authors have read and agreed to the published version of the manuscript.

Funding: This systematic review received no external funding.

Conflicts of Interest: None directly related to the materials discussed. Drake Lem, none. Dennis L. Gierhart is the Chief Scientific officer of and is employed by ZeaVision LLC. Pinakin Davey serves as a consultant to ZeaVision LLC, which manufactures various nutritional supplements-none of which were used in this study. He has received an honorarium as a speaker at lectures provided by ZeaVision and Guardion Health Sciences.

\section{References}

1. Quigley, H.A. Glaucoma. Lancet 2011, 377, 1367-1377. [CrossRef]

2. Quigley, H.A.; Broman, A.T. The number of people with glaucoma worldwide in 2010 and 2020. Br. J. Ophthalmol. 2006, 90, 262-267. [CrossRef]

3. Weinreb, R.N.; Aung, T.; Medeiros, F.A. The pathophysiology and treatment of glaucoma: A review. JAMA 2014, 311, 1901-1911. [CrossRef] [PubMed]

4. Tham, Y.C.; Li, X.; Wong, T.Y.; Quigley, H.A.; Aung, T.; Cheng, C.Y. Global prevalence of glaucoma and projections of glaucoma burden through 2040: A systematic review and meta-analysis. Ophthalmology 2014, 121, 2081-2090. [CrossRef] [PubMed]

5. National Eye Institute. Available online: https://www.nei.nih.gov/learn-about-eye-health/eye-conditions-and-diseases/ glaucoma (accessed on 13 January 2021).

6. Traverso, C.E.; Walt, J.G.; Kelly, S.P.; Hommer, A.H.; Bron, A.M.; Denis, P.; Nordmann, J.P.; Renard, J.P.; Bayer, A.; Grehn, F.; et al. Direct costs of glaucoma and severity of the disease: A multinational long term study of resource utilisation in Europe. Br. J. Ophthalmol. 2005, 89, 1245-1249. [CrossRef]

7. Collaborative Normal-Tension Glaucoma Study Group. Comparison of glaucomatous progression between untreated patients with normal-tension glaucoma and patients with therapeutically reduced intraocular pressures. Collaborative Normal-Tension Glaucoma Study Group. Am. J. Ophthalmol. 1998, 126, 487-497. [CrossRef]

8. Collaborative Normal-Tension Glaucoma Study Group. The effectiveness of intraocular pressure reduction in the treatment of normal-tension glaucoma. Collaborative Normal-Tension Glaucoma Study Group. Am. J. Ophthalmol. 1998, 126, $498-505$. [CrossRef]

9. Cook, C.; Foster, P. Epidemiology of glaucoma: What's new? Can. J. Ophthalmol. 2012, 47, 223-226. [CrossRef]

10. Gordon, M.O.; Beiser, J.A.; Brandt, J.D.; Heuer, D.K.; Higginbotham, E.J.; Johnson, C.A.; Keltner, J.L.; Miller, J.P.; Parrish, R.K., 2nd; Wilson, M.R.; et al. The Ocular Hypertension Treatment Study: Baseline factors that predict the onset of primary open-angle glaucoma. Arch. Ophthalmol. 2002, 120, 714-720. [CrossRef] 
11. Kapetanakis, V.V.; Chan, M.P.; Foster, P.J.; Cook, D.G.; Owen, C.G.; Rudnicka, A.R. Global variations and time trends in the prevalence of primary open angle glaucoma (POAG): A systematic review and meta-analysis. Br. J. Ophthalmol. 2016, 100, 86-93. [CrossRef]

12. Wolfs, R.C.; Klaver, C.C.; Ramrattan, R.S.; van Duijn, C.M.; Hofman, A.; de Jong, P.T. Genetic risk of primary open-angle glaucoma. Population-based familial aggregation study. Arch. Ophthalmol. 1998, 116, 1640-1645. [CrossRef]

13. Zhou, M.; Wang, W.; Huang, W.; Zhang, X. Diabetes mellitus as a risk factor for open-angle glaucoma: A systematic review and meta-analysis. PLoS ONE 2014, 9, e102972. [CrossRef]

14. Cohen, L.P.; Pasquale, L.R. Clinical characteristics and current treatment of glaucoma. Cold Spring Harb. Perspect. Med. 2014, 4, a017236. [CrossRef]

15. Lusthaus, J.; Goldberg, I. Current management of glaucoma. Med. J. Aust. 2019, 210, 180-187. [CrossRef] [PubMed]

16. Almasieh, M.; Wilson, A.M.; Morquette, B.; Cueva Vargas, J.L.; Di Polo, A. The molecular basis of retinal ganglion cell death in glaucoma. Prog. Retin. Eye Res. 2012, 31, 152-181. [CrossRef]

17. Nickells, R.W.; Howell, G.R.; Soto, I.; John, S.W. Under pressure: Cellular and molecular responses during glaucoma, a common neurodegeneration with axonopathy. Annu. Rev. Neurosci. 2012, 35, 153-179. [CrossRef]

18. Morrison, J.C.; Johnson, E.C.; Cepurna, W.; Jia, L. Understanding mechanisms of pressure-induced optic nerve damage. Prog. Retin. Eye Res. 2005, 24, 217-240. [CrossRef] [PubMed]

19. Tezel, G.; Yang, X.; Cai, J. Proteomic identification of oxidatively modified retinal proteins in a chronic pressure-induced rat model of glaucoma. Investig. Ophthalmol. Vis. Sci. 2005, 46, 3177-3187. [CrossRef] [PubMed]

20. Crish, S.D.; Calkins, D.J. Neurodegeneration in glaucoma: Progression and calcium-dependent intracellular mechanisms. Neuroscience 2011, 176, 1-11. [CrossRef]

21. Halliwell, B. Oxidative stress and neurodegeneration: Where are we now? J. Neurochem. 2006, 97, 1634-1658. [CrossRef]

22. Muriach, M.; Flores-Bellver, M.; Romero, F.J.; Barcia, J.M. Diabetes and the brain: Oxidative stress, inflammation, and autophagy. Oxid. Med. Cell. Longev. 2014, 2014, 102158. [CrossRef]

23. Gupta, N.; Yucel, Y.H. Glaucoma as a neurodegenerative disease. Curr. Opin. Ophthalmol. 2007, 18, 110-114. [CrossRef]

24. Adornetto, A.; Russo, R.; Parisi, V. Neuroinflammation as a target for glaucoma therapy. Neural. Regen. Res. 2019, 14, 391-394. [CrossRef]

25. Tang, B.; Li, S.; Cao, W.; Sun, X. The Association of Oxidative Stress Status with Open-Angle Glaucoma and Exfoliation Glaucoma: A Systematic Review and Meta-Analysis. J. Ophthalmol. 2019, 2019, 1803619. [CrossRef] [PubMed]

26. Beatty, S.; Boulton, M.; Henson, D.; Koh, H.H.; Murray, I.J. Macular pigment and age related macular degeneration. Br. J. Ophthalmol. 1999, 83, 867-877. [CrossRef] [PubMed]

27. Cai, J.; Nelson, K.C.; Wu, M.; Sternberg, P., Jr.; Jones, D.P. Oxidative damage and protection of the RPE. Prog. Retin. Eye Res. 2000, 19, 205-221. [CrossRef]

28. Kumar, D.M.; Agarwal, N. Oxidative stress in glaucoma: A burden of evidence. J. Glaucoma 2007, 16, 334-343. [CrossRef]

29. Sacca, S.C.; Cutolo, C.A.; Ferrari, D.; Corazza, P.; Traverso, C.E. The Eye, Oxidative Damage and Polyunsaturated Fatty Acids. Nutrients 2018, 10, 668. [CrossRef] [PubMed]

30. Osborne, N.N.; Nunez-Alvarez, C.; Joglar, B.; Del Olmo-Aguado, S. Glaucoma: Focus on mitochondria in relation to pathogenesis and neuroprotection. Eur J. Pharmacol. 2016, 787, 127-133. [CrossRef] [PubMed]

31. Georgieva, E.; Ivanova, D.; Zhelev, Z.; Bakalova, R.; Gulubova, M.; Aoki, I. Mitochondrial Dysfunction and Redox Imbalance as a Diagnostic Marker of "Free Radical Diseases". Anticancer Res. 2017, 37, 5373-5381. [CrossRef] [PubMed]

32. He, Y.; Ge, J.; Tombran-Tink, J. Mitochondrial defects and dysfunction in calcium regulation in glaucomatous trabecular meshwork cells. Investig. Ophthalmol. Vis. Sci. 2008, 49, 4912-4922. [CrossRef]

33. Kowluru, R.A.; Chan, P.S. Oxidative stress and diabetic retinopathy. Exp. Diabetes Res. 2007, 2007, 43603. [CrossRef]

34. Bernstein, P.S.; Li, B.; Vachali, P.P.; Gorusupudi, A.; Shyam, R.; Henriksen, B.S.; Nolan, J.M. Lutein, zeaxanthin, and mesozeaxanthin: The basic and clinical science underlying carotenoid-based nutritional interventions against ocular disease. Prog. Retin. Eye Res. 2016, 50, 34-66. [CrossRef] [PubMed]

35. Hammond, B.R., Jr.; Fletcher, L.M.; Elliott, J.G. Glare disability, photostress recovery, and chromatic contrast: Relation to macular pigment and serum lutein and zeaxanthin. Investig. Ophthalmol. Vis. Sci. 2013, 54, 476-481. [CrossRef]

36. Hammond, B.R.; Fletcher, L.M.; Roos, F.; Wittwer, J.; Schalch, W. A double-blind, placebo-controlled study on the effects of lutein and zeaxanthin on photostress recovery, glare disability, and chromatic contrast. Investig. Ophthalmol. Vis. Sci. 2014, 55, 8583-8589. [CrossRef]

37. Loughman, J.; Nolan, J.M.; Howard, A.N.; Connolly, E.; Meagher, K.; Beatty, S. The impact of macular pigment augmentation on visual performance using different carotenoid formulations. Investig. Ophthalmol. Vis. Sci. 2012, 53, 7871-7880. [CrossRef]

38. Ma, L.; Liu, R.; Du, J.H.; Liu, T.; Wu, S.S.; Liu, X.H. Lutein, Zeaxanthin and Meso-zeaxanthin Supplementation Associated with Macular Pigment Optical Density. Nutrients 2016, 8, 426. [CrossRef]

39. Nolan, J.M.; Loughman, J.; Akkali, M.C.; Stack, J.; Scanlon, G.; Davison, P.; Beatty, S. The impact of macular pigment augmentation on visual performance in normal subjects: COMPASS. Vision Res. 2011, 51, 459-469. [CrossRef]

40. Nolan, J.M.; Power, R.; Stringham, J.; Dennison, J.; Stack, J.; Kelly, D.; Moran, R.; Akuffo, K.O.; Corcoran, L.; Beatty, S. Enrichment of Macular Pigment Enhances Contrast Sensitivity in Subjects Free of Retinal Disease: Central Retinal Enrichment Supplementation Trials-Report 1. Investig. Ophthalmol. Vis. Sci. 2016, 57, 3429-3439. [CrossRef] 
41. Age-Related Eye Disease Study 2 Research Group. Lutein + zeaxanthin and omega-3 fatty acids for age-related macular degeneration: The Age-Related Eye Disease Study 2 (AREDS2) randomized clinical trial. JAMA 2013, 309, 2005-2015. [CrossRef]

42. Age-Related Eye Disease Study Research Group; SanGiovanni, J.P.; Chew, E.Y.; Clemons, T.E.; Ferris, F.L., 3rd; Gensler, G.; Lindblad, A.S.; Milton, R.C.; Seddon, J.M.; Sperduto, R.D. The relationship of dietary carotenoid and vitamin A, E, and C intake with age-related macular degeneration in a case-control study: AREDS Report No. 22. Arch. Ophthalmol. 2007, 125, 1225-1232. [CrossRef] [PubMed]

43. Davey, P.G.; Henderson, T.; Lem, D.W.; Weis, R.; Amonoo-Monney, S.; Evans, D.W. Visual Function and Macular Carotenoid Changes in Eyes with Retinal Drusen-An Open Label Randomized Controlled Trial to Compare a Micronized Lipid-Based Carotenoid Liquid Supplementation and AREDS-2 Formula. Nutrients 2020, 12, 3271. [CrossRef] [PubMed]

44. Chous, A.P.; Richer, S.P.; Gerson, J.D.; Kowluru, R.A. The Diabetes Visual Function Supplement Study (DiVFuSS). Br. J. Ophthalmol. 2016, 100, 227-234. [CrossRef] [PubMed]

45. Lem, D.W.; Gierhart, D.L.; Gunvant Davey, P. Management of Diabetic Eye Disease using Carotenoids and Nutrients. In Antioxidants; IntechOpen: London, UK, 2021.

46. Choi, J.S.; Kim, D.; Hong, Y.M.; Mizuno, S.; Joo, C.K. Inhibition of nNOS and COX-2 expression by lutein in acute retinal ischemia. Nutrition 2006, 22, 668-671. [CrossRef]

47. Dilsiz, N.; Sahaboglu, A.; Yildiz, M.Z.; Reichenbach, A. Protective effects of various antioxidants during ischemia-reperfusion in the rat retina. Graefes Arch. Clin. Exp. Ophthalmol. 2006, 244, 627-633. [CrossRef] [PubMed]

48. Fung, F.K.; Law, B.Y.; Lo, A.C. Lutein Attenuates Both Apoptosis and Autophagy upon Cobalt (II) Chloride-Induced Hypoxia in Rat Muller Cells. PLoS ONE 2016, 11, e0167828. [CrossRef]

49. Li, S.Y.; Fu, Z.J.; Ma, H.; Jang, W.C.; So, K.F.; Wong, D.; Lo, A.C. Effect of lutein on retinal neurons and oxidative stress in a model of acute retinal ischemia/reperfusion. Investig. Ophthalmol. Vis. Sci. 2009, 50, 836-843. [CrossRef]

50. Li, S.Y.; Fung, F.K.; Fu, Z.J.; Wong, D.; Chan, H.H.; Lo, A.C. Anti-inflammatory effects of lutein in retinal ischemic/hypoxic injury: In vivo and in vitro studies. Investig. Ophthalmol. Vis. Sci. 2012, 53, 5976-5984. [CrossRef]

51. Zhang, C.; Wang, Z.; Zhao, J.; Li, Q.; Huang, C.; Zhu, L.; Lu, D. Neuroprotective Effect of Lutein on NMDA-Induced Retinal Ganglion Cell Injury in Rat Retina. Cell Mol. Neurobiol. 2016, 36, 531-540. [CrossRef]

52. Ozawa, Y.; Sasaki, M.; Takahashi, N.; Kamoshita, M.; Miyake, S.; Tsubota, K. Neuroprotective effects of lutein in the retina. Curr. Pharm. Des. 2012, 18, 51-56. [CrossRef]

53. Davis, B.M.; Crawley, L.; Pahlitzsch, M.; Javaid, F.; Cordeiro, M.F. Glaucoma: The retina and beyond. Acta Neuropathol. 2016, 132, 807-826. [CrossRef] [PubMed]

54. Bruns, Y.; Junker, B.; Boehringer, D.; Framme, C.; Pielen, A. Comparison of Macular Pigment Optical Density in Glaucoma Patients and Healthy Subjects-A Prospective Diagnostic Study. Clin. Ophthalmol. 2020, 14, 1011-1017. [CrossRef]

55. Daga, F.B.; Ogata, N.G.; Medeiros, F.A.; Moran, R.; Morris, J.; Zangwill, L.M.; Weinreb, R.N.; Nolan, J.M. Macular Pigment and Visual Function in Patients with Glaucoma: The San Diego Macular Pigment Study. Investig. Ophthalmol. Vis. Sci. 2018, 59, 4471-4476. [CrossRef] [PubMed]

56. Igras, E.; Loughman, J.; Ratzlaff, M.; O'Caoimh, R.; O'Brien, C. Evidence of lower macular pigment optical density in chronic open angle glaucoma. Br. J. Ophthalmol. 2013, 97, 994-998. [CrossRef] [PubMed]

57. Ji, Y.; Zuo, C.; Lin, M.; Zhang, X.; Li, M.; Mi, L.; Liu, B.; Wen, F. Macular Pigment Optical Density in Chinese Primary Open Angle Glaucoma Using the One-Wavelength Reflectometry Method. J. Ophthalmol. 2016, 2016, 2792103. [CrossRef] [PubMed]

58. Siah, W.F.; Loughman, J.; O'Brien, C. Lower Macular Pigment Optical Density in Foveal-Involved Glaucoma. Ophthalmology 2015, 122, 2029-2037. [CrossRef] [PubMed]

59. Siah, W.F.; O'Brien, C.; Loughman, J.J. Macular pigment is associated with glare-affected visual function and central visual field loss in glaucoma. Br. J. Ophthalmol. 2018, 102, 929-935. [CrossRef]

60. Garcia-Medina, J.J.; Garcia-Medina, M.; Garrido-Fernandez, P.; Galvan-Espinosa, J.; Garcia-Maturana, C.; Zanon-Moreno, V.; Pinazo-Duran, M.D. A two-year follow-up of oral antioxidant supplementation in primary open-angle glaucoma: An open-label, randomized, controlled trial. Acta Ophthalmol. 2015, 93, 546-554. [CrossRef]

61. Romeo Villadoniga, S.; Rodriguez Garcia, E.; Sagastagoia Epelde, O.; Alvarez Diaz, M.D.; Domingo Pedrol, J.C. Effects of Oral Supplementation with Docosahexaenoic Acid (DHA) plus Antioxidants in Pseudoexfoliative Glaucoma: A 6-Month Open-Label Randomized Trial. J. Ophthalmol. 2018, 2018, 8259371. [CrossRef]

62. Sanz-Gonzalez, S.M.; Raga-Cervera, J.; Aguirre Lipperheide, M.; Zanon-Moreno, V.; Chiner, V.; Ramirez, A.I.; Pinazo-Duran, M.D. Effect of an oral supplementation with a formula containing R-lipoic acid in glaucoma patients. Arch. Soc. Esp. Oftalmol. 2020, 95, 120-129. [CrossRef]

63. Kamel, K.; Farrell, M.; O’Brien, C. Mitochondrial dysfunction in ocular disease: Focus on glaucoma. Mitochondrion 2017, 35, 44-53. [CrossRef]

64. Bratic, A.; Larsson, N.G. The role of mitochondria in aging. J. Clin. Investig. 2013, 123, 951-957. [CrossRef] [PubMed]

65. Pinazo-Durán, M.D.; Zanón-Moreno, V.; Gallego-Pinazo, R.; García-Medina, J.J. Chapter 6-Oxidative stress and mitochondrial failure in the pathogenesis of glaucoma neurodegeneration. In Progress in Brain Research; Bagetta, G., Nucci, C., Eds.; Elsevier: Amsterdam, The Netherlands, 2015; Volume 220, pp. 127-153.

66. Andersen, J.K. Oxidative stress in neurodegeneration: Cause or consequence? Nat. Med. 2004, 10, S18-S25. [CrossRef] 
67. Barnham, K.J.; Masters, C.L.; Bush, A.I. Neurodegenerative diseases and oxidative stress. Nat. Rev. Drug Discov. $2004,3,205-214$. [CrossRef]

68. Feilchenfeld, Z.; Yucel, Y.H.; Gupta, N. Oxidative injury to blood vessels and glia of the pre-laminar optic nerve head in human glaucoma. Exp. Eye Res. 2008, 87, 409-414. [CrossRef] [PubMed]

69. Yücel, Y.H.; Gupta, N. Central nervous system changes in glaucoma. In Ocular Disease; Elsevier: Amsterdam, The Netherlands, 2010; pp. 200-206.

70. Cobb, C.A.; Cole, M.P. Oxidative and nitrative stress in neurodegeneration. Neurobiol. Dis. 2015, 84, 4-21. [CrossRef]

71. Nucci, C.; Martucci, A.; Cesareo, M.; Garaci, F.; Morrone, L.A.; Russo, R.; Corasaniti, M.T.; Bagetta, G.; Mancino, R. Links among glaucoma, neurodegenerative, and vascular diseases of the central nervous system. Prog. Brain Res. 2015, 221, 49-65. [CrossRef] [PubMed]

72. Calkins, D.J. Critical pathogenic events underlying progression of neurodegeneration in glaucoma. Prog. Retin. Eye Res. 2012, 31, 702-719. [CrossRef] [PubMed]

73. Tanito, M.; Kaidzu, S.; Takai, Y.; Ohira, A. Status of systemic oxidative stresses in patients with primary open-angle glaucoma and pseudoexfoliation syndrome. PLoS ONE 2012, 7, e49680. [CrossRef]

74. Tanito, M.; Kaidzu, S.; Takai, Y.; Ohira, A. Association between systemic oxidative stress and visual field damage in open-angle glaucoma. Sci. Rep. 2016, 6, 25792. [CrossRef]

75. Elmore, S. Apoptosis: A review of programmed cell death. Toxicol. Pathol. 2007, 35, 495-516. [CrossRef] [PubMed]

76. Ghanem, A.A.; Arafa, L.F.; El-Baz, A. Oxidative stress markers in patients with primary open-angle glaucoma. Curr. Eye Res. 2010, 35, 295-301. [CrossRef] [PubMed]

77. Sacca, S.C.; Pascotto, A.; Camicione, P.; Capris, P.; Izzotti, A. Oxidative DNA damage in the human trabecular meshwork: Clinical correlation in patients with primary open-angle glaucoma. Arch. Ophthalmol. 2005, 123, 458-463. [CrossRef] [PubMed]

78. Weinreb, R.N.; Leung, C.K.; Crowston, J.G.; Medeiros, F.A.; Friedman, D.S.; Wiggs, J.L.; Martin, K.R. Primary open-angle glaucoma. Nat. Rev. Dis. Primers 2016, 2, 16067. [CrossRef] [PubMed]

79. Xu, H.; Chen, M.; Forrester, J.V. Para-inflammation in the aging retina. Prog. Retin. Eye Res. 2009, 28, 348-368. [CrossRef] [PubMed]

80. Chen, M.; Xu, H. Parainflammation, chronic inflammation, and age-related macular degeneration. J. Leukoc. Biol. 2015, 98, 713-725. [CrossRef]

81. Romano, G.L.; Amato, R.; Lazzara, F.; Porciatti, V.; Chou, T.-H.; Drago, F.; Bucolo, C. P2X7 receptor antagonism preserves retinal ganglion cells in glaucomatous mice. Biochem. Pharmacol. 2020, 180, 114199. [CrossRef] [PubMed]

82. Medzhitov, R. Origin and physiological roles of inflammation. Nature 2008, 454, 428-435. [CrossRef] [PubMed]

83. Liu, B.; Neufeld, A.H. Expression of nitric oxide synthase-2 (NOS-2) in reactive astrocytes of the human glaucomatous optic nerve head. Glia 2000, 30, 178-186. [CrossRef]

84. Neufeld, A.H.; Hernandez, M.R.; Gonzalez, M.; Geller, A. Cyclooxygenase-1 and cyclooxygenase-2 in the human optic nerve head. Exp. Eye Res. 1997, 65, 739-745. [CrossRef]

85. Tezel, G.; Li, L.Y.; Patil, R.V.; Wax, M.B. TNF-alpha and TNF-alpha receptor-1 in the retina of normal and glaucomatous eyes. Investig. Ophthalmol. Vis. Sci. 2001, 42, 1787-1794.

86. Dreyer, E.B.; Zurakowski, D.; Schumer, R.A.; Podos, S.M.; Lipton, S.A. Elevated glutamate levels in the vitreous body of humans and monkeys with glaucoma. Arch. Ophthalmol. 1996, 114, 299-305. [CrossRef]

87. Lotery, A.J. Glutamate excitotoxicity in glaucoma: Truth or fiction? Eye 2005, 19, 369-370. [CrossRef] [PubMed]

88. Ready, T. Stiff penalty for vision researcher guilty of scientific misconduct. Nat. Med. 2001, 7, 8. [CrossRef] [PubMed]

89. Honkanen, R.A.; Baruah, S.; Zimmerman, M.B.; Khanna, C.L.; Weaver, Y.K.; Narkiewicz, J.; Waziri, R.; Gehrs, K.M.; Weingeist, T.A.; Boldt, H.C.; et al. Vitreous amino acid concentrations in patients with glaucoma undergoing vitrectomy. Arch. Ophthalmol. 2003, 121, 183-188. [CrossRef]

90. Carter-Dawson, L.; Crawford, M.L.; Harwerth, R.S.; Smith, E.L., 3rd; Feldman, R.; Shen, F.F.; Mitchell, C.K.; Whitetree, A. Vitreal glutamate concentration in monkeys with experimental glaucoma. Investig. Ophthalmol. Vis. Sci. 2002, 43, 2633-2637. [PubMed]

91. Kwon, Y.H.; Rickman, D.W.; Baruah, S.; Zimmerman, M.B.; Kim, C.S.; Boldt, H.C.; Russell, S.R.; Hayreh, S.S. Vitreous and retinal amino acid concentrations in experimental central retinal artery occlusion in the primate. Eye 2005, 19, 455-463. [CrossRef] [PubMed]

92. Kemp, J.A.; McKernan, R.M. NMDA receptor pathways as drug targets. Nat. Neurosci. 2002, 5, 1039-1042. [CrossRef]

93. Niciu, M.J.; Kelmendi, B.; Sanacora, G. Overview of glutamatergic neurotransmission in the nervous system. Pharmacol. Biochem. Behav. 2012, 100, 656-664. [CrossRef]

94. Lewerenz, J.; Maher, P. Chronic Glutamate Toxicity in Neurodegenerative Diseases-What is the Evidence? Front. Neurosci. 2015, 9, 469. [CrossRef]

95. Medeiros, F.A.; Lisboa, R.; Weinreb, R.N.; Liebmann, J.M.; Girkin, C.; Zangwill, L.M. Retinal ganglion cell count estimates associated with early development of visual field defects in glaucoma. Ophthalmology 2013, 120, 736-744. [CrossRef]

96. Na, J.H.; Lee, K.; Lee, J.R.; Baek, S.; Yoo, S.J.; Kook, M.S. Detection of macular ganglion cell loss in preperimetric glaucoma patients with localized retinal nerve fibre defects by spectral-domain optical coherence tomography. Clin. Exp. Ophthalmol. 2013, 41, 870-880. [CrossRef] 
97. Zhang, X.; Loewen, N.; Tan, O.; Greenfield, D.S.; Schuman, J.S.; Varma, R.; Huang, D.; Advanced Imaging for Glaucoma Study Group. Predicting Development of Glaucomatous Visual Field Conversion Using Baseline Fourier-Domain Optical Coherence Tomography. Am. J. Ophthalmol. 2016, 163, 29-37. [CrossRef] [PubMed]

98. Scuderi, G.; Fragiotta, S.; Scuderi, L.; Iodice, C.M.; Perdicchi, A. Ganglion Cell Complex Analysis in Glaucoma Patients: What Can It Tell Us? Eye Brain 2020, 12, 33-44. [CrossRef]

99. Le, P.V.; Tan, O.; Chopra, V.; Francis, B.A.; Ragab, O.; Varma, R.; Huang, D. Regional correlation among ganglion cell complex, nerve fiber layer, and visual field loss in glaucoma. Investig. Ophthalmol. Vis. Sci. 2013, 54, 4287-4295. [CrossRef] [PubMed]

100. Gupta, N.; Ang, L.C.; Noel de Tilly, L.; Bidaisee, L.; Yucel, Y.H. Human glaucoma and neural degeneration in intracranial optic nerve, lateral geniculate nucleus, and visual cortex. Br. J. Ophthalmol. 2006, 90, 674-678. [CrossRef] [PubMed]

101. Yücel, Y.; Gupta, N. Glaucoma of the brain: A disease model for the study of transsynaptic neural degeneration. In Progress in Brain Research; Nucci, C., Cerulli, L., Osborne, N.N., Bagetta, G., Eds.; Elsevier: Amsterdam, The Netherlands, 2008; Volume 173, pp. 465-478.

102. Dinkin, M. Trans-synaptic Retrograde Degeneration in the Human Visual System: Slow, Silent, and Real. Curr. Neurol. Neurosci. Rep. 2017, 17, 16. [CrossRef] [PubMed]

103. Yucel, Y.H.; Zhang, Q.; Gupta, N.; Kaufman, P.L.; Weinreb, R.N. Loss of neurons in magnocellular and parvocellular layers of the lateral geniculate nucleus in glaucoma. Arch. Ophthalmol. 2000, 118, 378-384. [CrossRef]

104. Spear, P.D.; Kim, C.B.; Ahmad, A.; Tom, B.W. Relationship between numbers of retinal ganglion cells and lateral geniculate neurons in the rhesus monkey. Vis. Neurosci. 1996, 13, 199-203. [CrossRef]

105. Wang, J.; Li, T.; Sabel, B.A.; Chen, Z.; Wen, H.; Li, J.; Xie, X.; Yang, D.; Chen, W.; Wang, N.; et al. Structural brain alterations in primary open angle glaucoma: A 3T MRI study. Sci. Rep. 2016, 6, 18969. [CrossRef]

106. Bernstein, P.S.; Delori, F.C.; Richer, S.; van Kuijk, F.J.; Wenzel, A.J. The value of measurement of macular carotenoid pigment optical densities and distributions in age-related macular degeneration and other retinal disorders. Vision Res. 2010, 50, 716-728. [CrossRef]

107. Gruszecki, W.I.; Sielewiesiuk, J. Orientation of xanthophylls in phosphatidylcholine multibilayers. Biochim. Biophys. Acta 1990, 1023, 405-412. [CrossRef]

108. Bone, R.A.; Landrum, J.T.; Cao, Y.; Howard, A.N.; Alvarez-Calderon, F. Macular pigment response to a supplement containing meso-zeaxanthin, lutein and zeaxanthin. Nutr. Metab. 2007, 4, 12. [CrossRef]

109. Leung, I.Y. Macular pigment: New clinical methods of detection and the role of carotenoids in age-related macular degeneration. Optometry 2008, 79, 266-272. [CrossRef]

110. Howells, O.; Eperjesi, F.; Bartlett, H. Measuring macular pigment optical density in vivo: A review of techniques. Graefes Arch. Clin. Exp. Ophthalmol. 2011, 249, 315-347. [CrossRef]

111. de Kinkelder, R.; van der Veen, R.L.; Verbaak, F.D.; Faber, D.J.; van Leeuwen, T.G.; Berendschot, T.T. Macular pigment optical density measurements: Evaluation of a device using heterochromatic flicker photometry. Eye 2011, 25, 105-112. [CrossRef]

112. Li, B.; George, E.W.; Rognon, G.T.; Gorusupudi, A.; Ranganathan, A.; Chang, F.Y.; Shi, L.; Frederick, J.M.; Bernstein, P.S. Imaging lutein and zeaxanthin in the human retina with confocal resonance Raman microscopy. Proc. Natl. Acad. Sci. USA 2020, 117, 12352-12358. [CrossRef]

113. Bone, R.A.; Landrum, J.T.; Hime, G.W.; Cains, A.; Zamor, J. Stereochemistry of the human macular carotenoids. Investig. Ophthalmol. Vis. Sci. 1993, 34, 2033-2040.

114. Scripsema, N.K.; Hu, D.N.; Rosen, R.B. Lutein, Zeaxanthin, and meso-Zeaxanthin in the Clinical Management of Eye Disease. J. Ophthalmol. 2015, 2015, 865179. [CrossRef]

115. Bone, R.A.; Landrum, J.T.; Mayne, S.T.; Gomez, C.M.; Tibor, S.E.; Twaroska, E.E. Macular pigment in donor eyes with and without AMD: A case-control study. Investig. Ophthalmol. Vis. Sci. 2001, 42, 235-240.

116. Connor, W.E.; Duell, P.B.; Kean, R.; Wang, Y. The prime role of HDL to transport lutein into the retina: Evidence from HDLdeficient WHAM chicks having a mutant ABCA1 transporter. Investig. Ophthalmol. Vis. Sci. 2007, 48, 4226-4231. [CrossRef] [PubMed]

117. Gorusupudi, A.; Shyam, R.; Li, B.; Vachali, P.; Subhani, Y.K.; Nelson, K.; Bernstein, P.S. Developmentally Regulated Production of meso-Zeaxanthin in Chicken Retinal Pigment Epithelium/Choroid and Retina. Investig. Ophthalmol. Vis. Sci. 2016, 57, 1853-1861. [CrossRef] [PubMed]

118. Khachik, F.; de Moura, F.F.; Chew, E.Y.; Douglass, L.W.; Ferris, F.L., 3rd; Kim, J.; Thompson, D.J. The effect of lutein and zeaxanthin supplementation on metabolites of these carotenoids in the serum of persons aged 60 or older. Investig. Ophthalmol. Vis. Sci. 2006, 47, 5234-5242. [CrossRef] [PubMed]

119. Khachik, F.; de Moura, F.F.; Zhao, D.Y.; Aebischer, C.P.; Bernstein, P.S. Transformations of selected carotenoids in plasma, liver, and ocular tissues of humans and in nonprimate animal models. Investig. Ophthalmol. Vis. Sci. 2002, 43, 3383-3392.

120. Li, L.H.; Lee, J.C.; Leung, H.H.; Lam, W.C.; Fu, Z.; Lo, A.C.Y. Lutein Supplementation for Eye Diseases. Nutrients $2020,12,1721$. [CrossRef]

121. Shyam, R.; Gorusupudi, A.; Nelson, K.; Horvath, M.P.; Bernstein, P.S. RPE65 has an additional function as the lutein to meso-zeaxanthin isomerase in the vertebrate eye. Proc. Natl. Acad. Sci. USA 2017, 114, 10882-10887. [CrossRef] [PubMed]

122. Nagao, A. Absorption and metabolism of dietary carotenoids. BioFactors 2011, 37, 83-87. [CrossRef] [PubMed] 
123. Eisenhauer, B.; Natoli, S.; Liew, G.; Flood, V.M. Lutein and Zeaxanthin-Food Sources, Bioavailability and Dietary Variety in Age-Related Macular Degeneration Protection. Nutrients 2017, 9, 120. [CrossRef]

124. Howells, O.; Eperjesi, F.; Bartlett, H. Improving the repeatability of heterochromatic flicker photometry for measurement of macular pigment optical density. Graefes Arch. Clin. Exp. Ophthalmol. 2013, 251, 871-880. [CrossRef]

125. Junghans, A.; Sies, H.; Stahl, W. Macular pigments lutein and zeaxanthin as blue light filters studied in liposomes. Arch. Biochem. Biophys. 2001, 391, 160-164. [CrossRef]

126. Kijlstra, A.; Tian, Y.; Kelly, E.R.; Berendschot, T.T. Lutein: More than just a filter for blue light. Prog. Retin. Eye Res. 2012, 31, 303-315. [CrossRef] [PubMed]

127. Krinsky, N.I.; Johnson, E.J. Carotenoid actions and their relation to health and disease. Mol. Asp. Med. 2005, 26, 459-516. [CrossRef] [PubMed]

128. Landrum, J.T.; Bone, R.A. Mechanistic Evidence for Eye Disease and Carotenoids; Krinsky, N.I., Mayne, S.T., Sies, H., Eds.; CRC Press: New York, NY, USA, 2004.

129. Li, S.Y.; Fu, Z.J.; Lo, A.C. Hypoxia-induced oxidative stress in ischemic retinopathy. Oxid. Med. Cell. Longev. 2012, $2012,426769$. [CrossRef]

130. Lapierre-Landry, M.; Carroll, J.; Skala, M.C. Imaging retinal melanin: A review of current technologies. J. Biol. Eng. 2018, 12, 29. [CrossRef] [PubMed]

131. Yung, M.; Klufas, M.A.; Sarraf, D. Clinical applications of fundus autofluorescence in retinal disease. Int. J. Retin. Vitr. 2016, 2, 12. [CrossRef]

132. Delori, F.C.; Goger, D.G.; Hammond, B.R.; Snodderly, D.M.; Burns, S.A. Macular pigment density measured by autofluorescence spectrometry: Comparison with reflectometry and heterochromatic flicker photometry. J. Opt. Soc. Am. A Opt. Image Sci. Vis. 2001, 18, 1212-1230. [CrossRef]

133. Dennison, J.L.; Stack, J.; Beatty, S.; Nolan, J.M. Concordance of macular pigment measurements obtained using customized heterochromatic flicker photometry, dual-wavelength autofluorescence, and single-wavelength reflectance. Exp. Eye Res. 2013, 116, 190-198. [CrossRef]

134. Suarez-Berumen, K.; Davey, P.G. Macular Pigments Optical Density: A Review of Techniques of Measurements and Factors Influencing their Levels. JSM Ophthalmol. 2014, 3, 4.

135. Bartlett, H.; Howells, O.; Eperjesi, F. The role of macular pigment assessment in clinical practice: A review. Clin. Exp. Optom. 2010, 93, 300-308. [CrossRef]

136. Bartlett, H.; Eperjesi, F. Apparent motion photometry: Evaluation and reliability of a novel method for the measurement of macular pigment. Br. J. Ophthalmol. 2011, 95, 662-665. [CrossRef]

137. Davey, P.G.; Alvarez, S.D.; Lee, J.Y. Macular pigment optical density: Repeatability, intereye correlation, and effect of ocular dominance. Clin. Ophthalmol. 2016, 10, 1671-1678. [CrossRef]

138. Moreland, J.D. Macular pigment assessment by motion photometry. Arch. Biochem. Biophys. 2004, 430, 143-148. [CrossRef]

139. Lee, B.B.; Martin, P.R.; Valberg, A. The physiological basis of heterochromatic flicker photometry demonstrated in the ganglion cells of the macaque retina. J. Physiol. 1988, 404, 323-347. [CrossRef]

140. Obana, A.; Gohto, Y.; Moriyama, T.; Seto, T.; Sasano, H.; Okazaki, S. Reliability of a commercially available heterochromatic flicker photometer, the MPS2, for measuring the macular pigment optical density of a Japanese population. Jpn. J. Ophthalmol. 2018, 62, 473-480. [CrossRef] [PubMed]

141. Bone, R.A.; Mukherjee, A. Innovative Troxler-free measurement of macular pigment and lens density with correction of the former for the aging lens. J. Biomed. Opt. 2013, 18, 107003. [CrossRef] [PubMed]

142. Berendschot, T.T.; Goldbohm, R.A.; Klopping, W.A.; van de Kraats, J.; van Norel, J.; van Norren, D. Influence of lutein supplementation on macular pigment, assessed with two objective techniques. Investig. Ophthalmol. Vis. Sci. 2000, 41, 3322-3326.

143. Berendschot, T.T.; van Norren, D. Objective determination of the macular pigment optical density using fundus reflectance spectroscopy. Arch. Biochem. Biophys. 2004, 430, 149-155. [CrossRef] [PubMed]

144. Davey, P.G.; Ngo, A.; Cross, J.; Gierhart, D.L. Macular Pigment Reflectometry: Development and evaluation of a novel clinical device for rapid objective assessment of the macular carotenoids. In Ophthalmic Technologies XXIX; Manns, F., Soderberg, P.G., Ho, A., Eds.; SPIE: Bellingham, WA, USA, 2019; Volume 10858.

145. Huang, H.; Guan, C.; Ng, D.S.; Liu, X.; Chen, H. Macular Pigment Optical Density Measured by a Single Wavelength Reflection Photometry with and without Mydriasis. Curr. Eye Res. 2019, 44, 324-328. [CrossRef]

146. Kilbride, P.E.; Alexander, K.R.; Fishman, M.; Fishman, G.A. Human macular pigment assessed by imaging fundus reflectometry. Vision Res. 1989, 29, 663-674. [CrossRef]

147. Sanabria, J.C.; Bass, J.; Spors, F.; Gierhart, D.L.; Davey, P.G. Measurement of Carotenoids in Perifovea using the Macular Pigment Reflectometer. J. Vis. Exp. 2020, 9. [CrossRef] [PubMed]

148. Delori, F.C. Autofluorescence method to measure macular pigment optical densities fluorometry and autofluorescence imaging. Arch. Biochem. Biophys. 2004, 430, 156-162. [CrossRef] [PubMed]

149. You, Q.S.; Bartsch, D.U.; Espina, M.; Alam, M.; Camacho, N.; Mendoza, N.; Freeman, W.R. Reproducibility of Macular Pigment Optical Density Measurement by Two-Wavelength Autofluorescence in a Clinical Setting. Retina 2016, 36, 1381-1387. [CrossRef]

150. Christaras, D.; Ginis, H.; Pennos, A.; Mompean, J.; Artal, P. Objective method for measuring the macular pigment optical density in the eye. Biomed. Opt. Express 2019, 10, 3572-3583. [CrossRef] [PubMed] 
151. Bartlett, H.; Eperjesi, F. Use of fundus imaging in quantification of age-related macular change. Surv. Ophthalmol. 2007, 52, 655-671. [CrossRef] [PubMed]

152. Moher, D.; Liberati, A.; Tetzlaff, J.; Altman, D.G.; Group, P. Preferred reporting items for systematic reviews and meta-analyses: The PRISMA statement. J. Clin. Epidemiol. 2009, 62, 1006-1012. [CrossRef]

153. Coleman, A.L.; Stone, K.L.; Kodjebacheva, G.; Yu, F.; Pedula, K.L.; Ensrud, K.E.; Cauley, J.A.; Hochberg, M.C.; Topouzis, F.; Badala, F.; et al. Glaucoma risk and the consumption of fruits and vegetables among older women in the study of osteoporotic fractures. Am. J. Ophthalmol. 2008, 145, 1081-1089. [CrossRef] [PubMed]

154. Giaconi, J.A.; Yu, F.; Stone, K.L.; Pedula, K.L.; Ensrud, K.E.; Cauley, J.A.; Hochberg, M.C.; Coleman, A.L.; Study of Osteoporotic Fractures Research Group. The association of consumption of fruits/vegetables with decreased risk of glaucoma among older African-American women in the study of osteoporotic fractures. Am. J. Ophthalmol. 2012, 154, 635-644. [CrossRef]

155. Kang, J.H.; Pasquale, L.R.; Willett, W.; Rosner, B.; Egan, K.M.; Faberowski, N.; Hankinson, S.E. Antioxidant intake and primary open-angle glaucoma: A prospective study. Am. J. Epidemiol 2003, 158, 337-346. [CrossRef]

156. Kang, J.H.; Willett, W.C.; Rosner, B.A.; Buys, E.; Wiggs, J.L.; Pasquale, L.R. Association of Dietary Nitrate Intake with Primary Open-Angle Glaucoma: A Prospective Analysis from the Nurses' Health Study and Health Professionals Follow-up Study. JAMA Ophthalmol. 2016, 134, 294-303. [CrossRef] [PubMed]

157. Ramdas, W.D.; Wolfs, R.C.; Kiefte-de Jong, J.C.; Hofman, A.; de Jong, P.T.; Vingerling, J.R.; Jansonius, N.M. Nutrient intake and risk of open-angle glaucoma: The Rotterdam Study. Eur. J. Epidemiol. 2012, 27, 385-393. [CrossRef] [PubMed]

158. Hartsock, M.J.; Cho, H.; Wu, L.; Chen, W.J.; Gong, J.; Duh, E.J. A Mouse Model of Retinal Ischemia-Reperfusion Injury through Elevation of Intraocular Pressure. J. Vis. Exp. 2016. [CrossRef] [PubMed]

159. Hughes, W.F. Quantitation of ischemic damage in the rat retina. Exp. Eye Res. 1991, 53, 573-582. [CrossRef]

160. Buchi, E.R.; Suivaizdis, I.; Fu, J. Pressure-induced retinal ischemia in rats: An experimental model for quantitative study. Ophthalmologica 1991, 203, 138-147. [CrossRef]

161. Buchi, E.R. Cell death in the rat retina after a pressure-induced ischaemia-reperfusion insult: An electron microscopic study. I. Ganglion cell layer and inner nuclear layer. Exp. Eye Res. 1992, 55, 605-613. [CrossRef]

162. Masuzawa, K.; Jesmin, S.; Maeda, S.; Kaji, Y.; Oshika, T.; Zaedi, S.; Shimojo, N.; Yaji, N.; Miyauchi, T.; Goto, K. A model of retinal ischemia-reperfusion injury in rats by subconjunctival injection of endothelin-1. Exp. Biol. Med. 2006, 231, 1085-1089. [CrossRef]

163. Ansari, S.; Azari, H.; McConnell, D.J.; Afzal, A.; Mocco, J. Intraluminal middle cerebral artery occlusion (MCAO) model for ischemic stroke with laser doppler flowmetry guidance in mice. J. Vis. Exp. 2011, 2879. [CrossRef] [PubMed]

164. Rosenbaum, D.M.; Rosenbaum, P.S.; Singh, M.; Gupta, G.; Gupta, H.; Li, B.; Roth, S. Functional and morphologic comparison of two methods to produce transient retinal ischemia in the rat. J. Neuro Ophthalmol. 2001, 21, 62-68. [CrossRef]

165. Liu, F.; McCullough, L.D. Middle cerebral artery occlusion model in rodents: Methods and potential pitfalls. J. Biomed. Biotechnol. 2011, 2011, 464701. [CrossRef]

166. Sarthy, V.P.; Brodjian, S.J.; Dutt, K.; Kennedy, B.N.; French, R.P.; Crabb, J.W. Establishment and characterization of a retinal Muller cell line. Investig. Ophthalmol. Vis. Sci. 1998, 39, 212-216. [PubMed]

167. Siliprandi, R.; Lipartiti, M.; Fadda, E.; Sautter, J.; Manev, H. Activation of the glutamate metabotropic receptor protects retina against N-methyl-D-aspartate toxicity. Eur. J. Pharmacol. 1992, 219, 173-174. [CrossRef]

168. Johnson, E.J. Role of lutein and zeaxanthin in visual and cognitive function throughout the lifespan. Nutr. Rev. 2014, 72, 605-612. [CrossRef] [PubMed]

169. Wang, H.; Zhang, C.; Lu, D.; Shu, X.; Zhu, L.; Qi, R.; So, K.F.; Lu, D.; Xu, Y. Oligomeric proanthocyanidin protects retinal ganglion cells against oxidative stress-induced apoptosis. Neural Regen. Res. 2013, 8, 2317-2326. [CrossRef] [PubMed]

170. Aslan, M.; Yucel, I.; Akar, Y.; Yucel, G.; Ciftcioglu, M.A.; Sanlioglu, S. Nitrotyrosine formation and apoptosis in rat models of ocular injury. Free Radic. Res. 2006, 40, 147-153. [CrossRef] [PubMed]

171. Toda, N.; Nakanishi-Toda, M. Nitric oxide: Ocular blood flow, glaucoma, and diabetic retinopathy. Prog. Retin. Eye Res. 2007, 26, 205-238. [CrossRef] [PubMed]

172. Lopez-Sanchez, C.; Martin-Romero, F.J.; Sun, F.; Luis, L.; Samhan-Arias, A.K.; Garcia-Martinez, V.; Gutierrez-Merino, C. Blood micromolar concentrations of kaempferol afford protection against ischemia/reperfusion-induced damage in rat brain. Brain Res. 2007, 1182, 123-137. [CrossRef]

173. Pinazo-Duran, M.D.; Shoaie-Nia, K.; Zanon-Moreno, V.; Sanz-Gonzalez, S.M.; Del Castillo, J.B.; Garcia-Medina, J.J. Strategies to Reduce Oxidative Stress in Glaucoma Patients. Curr. NeuroPharmacol. 2018, 16, 903-918. [CrossRef] [PubMed]

174. Tezel, G. Oxidative stress in glaucomatous neurodegeneration: Mechanisms and consequences. Prog. Retin. Eye Res. 2006, 25, 490-513. [CrossRef] [PubMed]

175. Mousa, A.; Kondkar, A.A.; Al-Obeidan, S.A.; Azad, T.A.; Sultan, T.; Osman, E.; Abu-Amero, K.K. Association of total antioxidants level with glaucoma type and severity. Saudi Med. J. 2015, 36, 671-677. [CrossRef] [PubMed]

176. Abu-Amero, K.K.; Kondkar, A.A.; Mousa, A.; Osman, E.A.; Al-Obeidan, S.A. Decreased total antioxidants in patients with primary open angle glaucoma. Curr. Eye Res. 2013, 38, 959-964. [CrossRef] [PubMed]

177. Arnal, E.; Miranda, M.; Johnsen-Soriano, S.; Alvarez-Nolting, R.; Diaz-Llopis, M.; Araiz, J.; Cervera, E.; Bosch-Morell, F.; Romero, F.J. Beneficial effect of docosahexanoic acid and lutein on retinal structural, metabolic, and functional abnormalities in diabetic rats. Curr. Eye Res. 2009, 34, 928-938. [CrossRef] [PubMed] 
178. Kowluru, R.A.; Menon, B.; Gierhart, D.L. Beneficial effect of zeaxanthin on retinal metabolic abnormalities in diabetic rats. Investig. Ophthalmol. Vis. Sci. 2008, 49, 1645-1651. [CrossRef] [PubMed]

179. Muriach, M.; Bosch-Morell, F.; Alexander, G.; Blomhoff, R.; Barcia, J.; Arnal, E.; Almansa, I.; Romero, F.J.; Miranda, M. Lutein effect on retina and hippocampus of diabetic mice. Free Radic. Biol. Med. 2006, 41, 979-984. [CrossRef] [PubMed]

180. Neelam, K.; Goenadi, C.J.; Lun, K.; Yip, C.C.; Au Eong, K.G. Putative protective role of lutein and zeaxanthin in diabetic retinopathy. Br. J. Ophthalmol. 2017, 101, 551-558. [CrossRef] [PubMed]

181. Izumi-Nagai, K.; Nagai, N.; Ohgami, K.; Satofuka, S.; Ozawa, Y.; Tsubota, K.; Umezawa, K.; Ohno, S.; Oike, Y.; Ishida, S. Macular pigment lutein is antiinflammatory in preventing choroidal neovascularization. Arterioscler. Thromb. Vasc. Biol. 2007, 27, 2555-2562. [CrossRef]

182. Bian, Q.; Gao, S.; Zhou, J.; Qin, J.; Taylor, A.; Johnson, E.J.; Tang, G.; Sparrow, J.R.; Gierhart, D.; Shang, F. Lutein and zeaxanthin supplementation reduces photooxidative damage and modulates the expression of inflammation-related genes in retinal pigment epithelial cells. Free Radic. Biol. Med. 2012, 53, 1298-1307. [CrossRef] [PubMed]

183. Kuchtey, J.; Rezaei, K.A.; Jaru-Ampornpan, P.; Sternberg, P., Jr.; Kuchtey, R.W. Multiplex cytokine analysis reveals elevated concentration of interleukin-8 in glaucomatous aqueous humor. Investig. Ophthalmol. Vis. Sci. 2010, 51, 6441-6447. [CrossRef]

184. Abcouwer, S.F. Angiogenic Factors and Cytokines in Diabetic Retinopathy. J. Clin. Cell Immunol. 2013. [CrossRef]

185. Kowluru, R.A.; Koppolu, P.; Chakrabarti, S.; Chen, S. Diabetes-induced activation of nuclear transcriptional factor in the retina, and its inhibition by antioxidants. Free Radic. Res. 2003, 37, 1169-1180. [CrossRef]

186. Tak, P.P.; Firestein, G.S. NF-kappaB: A key role in inflammatory diseases. J. Clin. Investig. 2001, 107, 7-11. [CrossRef]

187. Li, S.Y.; Yang, D.; Fu, Z.J.; Woo, T.; Wong, D.; Lo, A.C. Lutein enhances survival and reduces neuronal damage in a mouse model of ischemic stroke. Neurobiol. Dis. 2012, 45, 624-632. [CrossRef]

188. Alt, F. Advances in Immunology, Volume 95; Academic Press: Salt Lake, UT, USA, 2007.

189. Liu, T.; Zhang, L.; Joo, D.; Sun, S.C. NF-kappaB signaling in inflammation. Signal. Transduct. Target. Ther. 2017, 2, 17023. [CrossRef]

190. Pahl, H.L. Activators and target genes of Rel/NF-kappaB transcription factors. Oncogene 1999, 18, 6853-6866. [CrossRef]

191. Sun, S.C. The non-canonical NF-kappaB pathway in immunity and inflammation. Nat. Rev. Immunol. 2017, 17, 545-558. [CrossRef] [PubMed]

192. Kowluru, R.A.; Odenbach, S. Role of interleukin-1beta in the development of retinopathy in rats: Effect of antioxidants. Investig. Ophthalmol. Vis. Sci. 2004, 45, 4161-4166. [CrossRef]

193. Dejardin, E. The alternative NF-kappaB pathway from biochemistry to biology: Pitfalls and promises for future drug development. Biochem. Pharmacol. 2006, 72, 1161-1179. [CrossRef]

194. Bringmann, A.; Wiedemann, P. Muller glial cells in retinal disease. Ophthalmologica 2012, 227, 1-19. [CrossRef] [PubMed]

195. Eastlake, K.; Banerjee, P.J.; Angbohang, A.; Charteris, D.G.; Khaw, P.T.; Limb, G.A. Muller glia as an important source of cytokines and inflammatory factors present in the gliotic retina during proliferative vitreoretinopathy. Glia 2016, 64, 495-506. [CrossRef] [PubMed]

196. Wang, M.; Ma, W.; Zhao, L.; Fariss, R.N.; Wong, W.T. Adaptive Muller cell responses to microglial activation mediate neuroprotection and coordinate inflammation in the retina. J. Neuroinflammation 2011, 8, 173. [CrossRef] [PubMed]

197. Wang, M.; Wong, W.T. Microglia-Müller Cell Interactions in the Retina; Springer: New York, NY, USA, $2014 ;$ pp. $333-338$.

198. Ramirez, A.I.; de Hoz, R.; Salobrar-Garcia, E.; Salazar, J.J.; Rojas, B.; Ajoy, D.; Lopez-Cuenca, I.; Rojas, P.; Trivino, A.; Ramirez, J.M. The Role of Microglia in Retinal Neurodegeneration: Alzheimer's Disease, Parkinson, and Glaucoma. Front. Aging Neurosci. 2017, 9, 214. [CrossRef] [PubMed]

199. Soto, I.; Howell, G.R. The complex role of neuroinflammation in glaucoma. Cold Spring Harb. Perspect. Med. 2014, 4, a017269. [CrossRef] [PubMed]

200. Yuan, L.; Neufeld, A.H. Activated microglia in the human glaucomatous optic nerve head. J. Neurosci. Res. 2001, 64, 523-532. [CrossRef] [PubMed]

201. Quigley, H.A.; Nickells, R.W.; Kerrigan, L.A.; Pease, M.E.; Thibault, D.J.; Zack, D.J. Retinal ganglion cell death in experimental glaucoma and after axotomy occurs by apoptosis. Investig. Ophthalmol. Vis. Sci. 1995, 36, 774-786. [PubMed]

202. Kerrigan, L.A.; Zack, D.J.; Quigley, H.A.; Smith, S.D.; Pease, M.E. TUNEL-positive ganglion cells in human primary open-angle glaucoma. Arch. Ophthalmol. 1997, 115, 1031-1035. [CrossRef] [PubMed]

203. Lam, T.T.; Abler, A.S.; Tso, M.O. Apoptosis and caspases after ischemia-reperfusion injury in rat retina. Investig. Ophthalmol. Vis. Sci. 1999, 40, 967-975.

204. Kaja, S.; Yang, S.H.; Wei, J.; Fujitani, K.; Liu, R.; Brun-Zinkernagel, A.M.; Simpkins, J.W.; Inokuchi, K.; Koulen, P. Estrogen protects the inner retina from apoptosis and ischemia-induced loss of Vesl-1L/Homer 1c immunoreactive synaptic connections. Investig. Ophthalmol. Vis. Sci. 2003, 44, 3155-3162. [CrossRef] [PubMed]

205. Sasaki, M.; Ozawa, Y.; Kurihara, T.; Kubota, S.; Yuki, K.; Noda, K.; Kobayashi, S.; Ishida, S.; Tsubota, K. Neurodegenerative influence of oxidative stress in the retina of a murine model of diabetes. Diabetologia 2010, 53, 971-979. [CrossRef] [PubMed]

206. Sasaki, M.; Yuki, K.; Kurihara, T.; Miyake, S.; Noda, K.; Kobayashi, S.; Ishida, S.; Tsubota, K.; Ozawa, Y. Biological role of lutein in the light-induced retinal degeneration. J. Nutr. Biochem. 2012, 23, 423-429. [CrossRef] [PubMed]

207. Sasaki, M.; Ozawa, Y.; Kurihara, T.; Noda, K.; Imamura, Y.; Kobayashi, S.; Ishida, S.; Tsubota, K. Neuroprotective effect of an antioxidant, lutein, during retinal inflammation. Investig. Ophthalmol. Vis. Sci. 2009, 50, 1433-1439. [CrossRef] 
208. Jung, J.Y.; Roh, K.H.; Jeong, Y.J.; Kim, S.H.; Lee, E.J.; Kim, M.S.; Oh, W.M.; Oh, H.K.; Kim, W.J. Estradiol protects PC12 cells against CoCl2-induced apoptosis. Brain Res. Bull. 2008, 76, 579-585. [CrossRef] [PubMed]

209. Li, L.; Wu, W.; Huang, W.; Hu, G.; Yuan, W.; Li, W. NF-kappaB RNAi decreases the Bax/Bcl-2 ratio and inhibits TNF-alpha-induced apoptosis in human alveolar epithelial cells. Inflamm. Res. 2013, 62, 387-397. [CrossRef]

210. Osborne, N.N. Mitochondria: Their role in ganglion cell death and survival in primary open angle glaucoma. Exp. Eye Res. 2010, 90, 750-757. [CrossRef] [PubMed]

211. Ola, M.S.; Nawaz, M.; Ahsan, H. Role of Bcl-2 family proteins and caspases in the regulation of apoptosis. Mol. Cell Biochem. 2011, 351, 41-58. [CrossRef]

212. Wang, C.; Youle, R.J. The role of mitochondria in apoptosis. Annu Rev. Genet. 2009, 43, 95-118. [CrossRef]

213. Yip, K.W.; Reed, J.C. Bcl-2 family proteins and cancer. Oncogene 2008, 27, 6398-6406. [CrossRef] [PubMed]

214. Vince, J.E.; De Nardo, D.; Gao, W.; Vince, A.J.; Hall, C.; McArthur, K.; Simpson, D.; Vijayaraj, S.; Lindqvist, L.M.; Bouillet, P.; et al. The Mitochondrial Apoptotic Effectors BAX/BAK Activate Caspase-3 and -7 to Trigger NLRP3 Inflammasome and Caspase-8 Driven IL-1beta Activation. Cell Rep. 2018, 25, 2339-2353.e2334. [CrossRef] [PubMed]

215. Kiang, J.G.; Fukumoto, R.; Gorbunov, N.V. Lipid Peroxidation after Ionizing Irradiation Leads to Apoptosis and Autophagy. In Lipid Peroxidation; IntechOpen: London, UK, 2012.

216. Ashhurst, T.M.; van Vreden, C.; Niewold, P.; King, N.J. The plasticity of inflammatory monocyte responses to the inflamed central nervous system. Cell Immunol. 2014, 291, 49-57. [CrossRef] [PubMed]

217. Bosco, A.; Crish, S.D.; Steele, M.R.; Romero, C.O.; Inman, D.M.; Horner, P.J.; Calkins, D.J.; Vetter, M.L. Early reduction of microglia activation by irradiation in a model of chronic glaucoma. PLoS ONE 2012, 7, e43602. [CrossRef] [PubMed]

218. Ebneter, A.; Casson, R.J.; Wood, J.P.; Chidlow, G. Microglial activation in the visual pathway in experimental glaucoma: Spatiotemporal characterization and correlation with axonal injury. Investig. Ophthalmol. Vis. Sci. 2010, 51, 6448-6460. [CrossRef]

219. Glass, C.K.; Saijo, K.; Winner, B.; Marchetto, M.C.; Gage, F.H. Mechanisms underlying inflammation in neurodegeneration. Cell 2010, 140, 918-934. [CrossRef]

220. Wei, X.; Yu, Z.; Cho, K.S.; Chen, H.; Malik, M.T.; Chen, X.; Lo, E.H.; Wang, X.; Chen, D.F. Neuroglobin is an endogenous neuroprotectant for retinal ganglion cells against glaucomatous damage. Am. J. Pathol. 2011, 179, 2788-2797. [CrossRef] [PubMed]

221. Danbolt, N.C. Glutamate uptake. Prog. Neurobiol. 2001, 65, 1-105. [CrossRef]

222. Fahrenthold, B.K.; Fernandes, K.A.; Libby, R.T. Assessment of intrinsic and extrinsic signaling pathway in excitotoxic retinal ganglion cell death. Sci. Rep. 2018, 8, 4641. [CrossRef] [PubMed]

223. Lipton, S.A.; Rosenberg, P.A. Excitatory amino acids as a final common pathway for neurologic disorders. N. Engl. J. Med. 1994, 330, 613-622. [CrossRef] [PubMed]

224. Green, D.R.; Reed, J.C. Mitochondria and apoptosis. Science 1998, 281, 1309-1312. [CrossRef]

225. Savolainen, K.M.; Loikkanen, J.; Naarala, J. Amplification of glutamate-induced oxidative stress. Toxicol. Lett. 1995, 82-83, 399-405. [CrossRef]

226. Siliprandi, R.; Canella, R.; Carmignoto, G.; Schiavo, N.; Zanellato, A.; Zanoni, R.; Vantini, G. N-methyl-D-aspartate-induced neurotoxicity in the adult rat retina. Vis. Neurosci. 1992, 8, 567-573. [CrossRef]

227. Salinas-Navarro, M.; Alarcon-Martinez, L.; Valiente-Soriano, F.J.; Jimenez-Lopez, M.; Mayor-Torroglosa, S.; Aviles-Trigueros, M.; Villegas-Perez, M.P.; Vidal-Sanz, M. Ocular hypertension impairs optic nerve axonal transport leading to progressive retinal ganglion cell degeneration. Exp. Eye Res. 2010, 90, 168-183. [CrossRef] [PubMed]

228. Chevalier-Larsen, E.; Holzbaur, E.L. Axonal transport and neurodegenerative disease. Biochim. Biophys. Acta 2006, 1762, 1094-1108. [CrossRef]

229. Crish, S.D.; Sappington, R.M.; Inman, D.M.; Horner, P.J.; Calkins, D.J. Distal axonopathy with structural persistence in glaucomatous neurodegeneration. Proc. Natl. Acad. Sci. USA 2010, 107, 5196-5201. [CrossRef] [PubMed]

230. Fahy, E.T.; Chrysostomou, V.; Crowston, J.G. Mini-Review: Impaired Axonal Transport and Glaucoma. Curr. Eye Res. 2016, 41, 273-283. [CrossRef]

231. Anderson, D.R.; Hendrickson, A. Effect of intraocular pressure on rapid axoplasmic transport in monkey optic nerve. Investig. Ophthalmol. 1974, 13, 771-783. [PubMed]

232. Johansson, J.O. Retrograde axoplasmic transport in rat optic nerve in vivo. What causes blockage at increased intraocular pressure? Exp. Eye Res. 1986, 43, 653-660. [CrossRef]

233. Kalamkarov, G.R.; Tsapenko, I.V.; Zueva, M.V.; Ivanov, A.N.; Konstantinova, T.S.; Bugrova, A.E.; Rezvykh, S.V.; Fedorov, A.A.; Shevchenko, T.F. Experimental model of acute ischemia of the retina in rats. Bull. Exp. Biol. Med. 2008, 145, 688-691. [CrossRef]

234. Matsui, Y.; Katsumi, O.; Mehta, M.C.; Hirose, T. Correlation of electroretinographic and fluorescein angiographic findings in unilateral central retinal vein obstruction. Graefes Arch. Clin. Exp. Ophthalmol. 1994, 232, 449-457. [CrossRef] [PubMed]

235. Osborne, N.N.; Casson, R.J.; Wood, J.P.; Chidlow, G.; Graham, M.; Melena, J. Retinal ischemia: Mechanisms of damage and potential therapeutic strategies. Prog. Retin. Eye Res. 2004, 23, 91-147. [CrossRef] [PubMed]

236. Sabates, R.; Hirose, T.; McMeel, J.W. Electroretinography in the prognosis and classification of central retinal vein occlusion. Arch. Ophthalmol. 1983, 101, 232-235. [CrossRef] [PubMed]

237. Krishnamoorthy, R.R.; Agarwal, P.; Prasanna, G.; Vopat, K.; Lambert, W.; Sheedlo, H.J.; Pang, I.H.; Shade, D.; Wordinger, R.J.; Yorio, T.; et al. Retraction notice to "Characterization of a transformed rat retinal ganglion cell line" [Brain Res. Mol. Brain Res. 86 (2001) 1-12]. Brain Res. 2014, 1544, 62. [CrossRef] [PubMed] 
238. Agarwal, N. RGC-5 cells. Investig. Ophthalmol. Vis. Sci. 2013, 54, 7884. [CrossRef] [PubMed]

239. Krishnamoorthy, R.R.; Clark, A.F.; Daudt, D.; Vishwanatha, J.K.; Yorio, T. A forensic path to RGC-5 cell line identification: Lessons learned. Investig. Ophthalmol. Vis. Sci. 2013, 54, 5712-5719. [CrossRef] [PubMed]

240. Li, S.Y.; Lo, A.C. Lutein protects RGC-5 cells against hypoxia and oxidative stress. Int. J. Mol. Sci. 2010, 11, 2109-2117. [CrossRef]

241. Nakajima, Y.; Shimazawa, M.; Otsubo, K.; Ishibashi, T.; Hara, H. Zeaxanthin, a retinal carotenoid, protects retinal cells against oxidative stress. Curr. Eye Res. 2009, 34, 311-318. [CrossRef] [PubMed]

242. al-Ubaidi, M.R.; Font, R.L.; Quiambao, A.B.; Keener, M.J.; Liou, G.I.; Overbeek, P.A.; Baehr, W. Bilateral retinal and brain tumors in transgenic mice expressing simian virus 40 large $\mathrm{T}$ antigen under control of the human interphotoreceptor retinoid-binding protein promoter. J. Cell Biol. 1992, 119, 1681-1687. [CrossRef] [PubMed]

243. Aoun, P.; Simpkins, J.W.; Agarwal, N. Role of PPAR-gamma ligands in neuroprotection against glutamate-induced cytotoxicity in retinal ganglion cells. Investig. Ophthalmol. Vis. Sci. 2003, 44, 2999-3004. [CrossRef] [PubMed]

244. Van Bergen, N.J.; Wood, J.P.; Chidlow, G.; Trounce, I.A.; Casson, R.J.; Ju, W.K.; Weinreb, R.N.; Crowston, J.G. Recharacterization of the RGC-5 retinal ganglion cell line. Investig. Ophthalmol. Vis. Sci. 2009, 50, 4267-4272. [CrossRef] [PubMed]

245. Xue, C.; Rosen, R.; Jordan, A.; Hu, D.N. Management of Ocular Diseases Using Lutein and Zeaxanthin: What Have We Learned from Experimental Animal Studies? J. Ophthalmol. 2015, 2015, 523027. [CrossRef] [PubMed]

246. Nucci, C.; Di Pierro, D.; Varesi, C.; Ciuffoletti, E.; Russo, R.; Gentile, R.; Cedrone, C.; Pinazo Duran, M.D.; Coletta, M.; Mancino, R Increased malondialdehyde concentration and reduced total antioxidant capacity in aqueous humor and blood samples from patients with glaucoma. Mol. Vis. 2013, 19, 1841-1846.

247. Sorkhabi, R.; Ghorbanihaghjo, A.; Javadzadeh, A.; Rashtchizadeh, N.; Moharrery, M. Oxidative DNA damage and total antioxidant status in glaucoma patients. Mol. Vis. 2011, 17, 41-46. [PubMed]

248. Ferreira, S.M.; Lerner, S.F.; Brunzini, R.; Evelson, P.A.; Llesuy, S.F. Oxidative stress markers in aqueous humor of glaucoma patients. Am. J. Ophthalmol. 2004, 137, 62-69. [CrossRef]

249. Nita, M.; Grzybowski, A. The Role of the Reactive Oxygen Species and Oxidative Stress in the Pathomechanism of the Age-Related Ocular Diseases and Other Pathologies of the Anterior and Posterior Eye Segments in Adults. Oxid. Med. Cell. Longev. 2016, 2016, 3164734. [CrossRef]

250. Freeman, E.E.; Gange, S.J.; Munoz, B.; West, S.K. Driving status and risk of entry into long-term care in older adults. Am. J. Public Health 2006, 96, 1254-1259. [CrossRef] [PubMed]

251. Goyal, A.; Srivastava, A.; Sihota, R.; Kaur, J. Evaluation of oxidative stress markers in aqueous humor of primary open angle glaucoma and primary angle closure glaucoma patients. Curr. Eye Res. 2014, 39, 823-829. [CrossRef]

252. Yildirim, O.; Ates, N.A.; Ercan, B.; Muslu, N.; Unlu, A.; Tamer, L.; Atik, U.; Kanik, A. Role of oxidative stress enzymes in open-angle glaucoma. Eye 2005, 19, 580-583. [CrossRef]

253. Benoist d'Azy, C.; Pereira, B.; Chiambaretta, F.; Dutheil, F. Oxidative and Anti-Oxidative Stress Markers in Chronic Glaucoma: A Systematic Review and Meta-Analysis. PLoS ONE 2016, 11, e0166915. [CrossRef]

254. Abdel-Aal el, S.M.; Akhtar, H.; Zaheer, K.; Ali, R. Dietary sources of lutein and zeaxanthin carotenoids and their role in eye health. Nutrients 2013, 5, 1169-1185. [CrossRef] [PubMed]

255. Maiani, G.; Caston, M.J.; Catasta, G.; Toti, E.; Cambrodon, I.G.; Bysted, A.; Granado-Lorencio, F.; Olmedilla-Alonso, B.; Knuthsen, P.; Valoti, M.; et al. Carotenoids: Actual knowledge on food sources, intakes, stability and bioavailability and their protective role in humans. Mol. Nutr. Food Res. 2009, 53 (Suppl. 2), S194-S218. [CrossRef]

256. Flammer, J.; Konieczka, K.; Flammer, A.J. The primary vascular dysregulation syndrome: Implications for eye diseases. EPMA J. 2013, 4, 14. [CrossRef]

257. Park, S.C.; De Moraes, C.G.; Teng, C.C.; Tello, C.; Liebmann, J.M.; Ritch, R. Initial parafoveal versus peripheral scotomas in glaucoma: Risk factors and visual field characteristics. Ophthalmology 2011, 118, 1782-1789. [CrossRef] [PubMed]

258. Kumari, N.; Cher, J.; Chua, E.; Hamzah, H.; Wong, T.Y.; Cheung, C.Y. Association of serum lutein and zeaxanthin with quantitative measures of retinal vascular parameters. PLoS ONE 2018, 13, e0203868. [CrossRef]

259. Mitchell, P.; Leung, H.; Wang, J.J.; Rochtchina, E.; Lee, A.J.; Wong, T.Y.; Klein, R. Retinal vessel diameter and open-angle glaucoma: The Blue Mountains Eye Study. Ophthalmology 2005, 112, 245-250. [CrossRef] [PubMed]

260. Jeganathan, V.S.; Kawasaki, R.; Wang, J.J.; Aung, T.; Mitchell, P.; Saw, S.M.; Wong, T.Y. Retinal vascular caliber and age-related macular degeneration: The Singapore Malay Eye Study. Am. J. Ophthalmol. 2008, 146, 954-959.e951. [CrossRef] [PubMed]

261. Leske, M.C. Ocular perfusion pressure and glaucoma: Clinical trial and epidemiologic findings. Curr. Opin. Ophthalmol. 2009, 20, 73-78. [CrossRef] [PubMed]

262. Perry, A.; Rasmussen, H.; Johnson, E.J. Xanthophyll (lutein, zeaxanthin) content in fruits, vegetables and corn and egg products. J. Food Compos. Anal. 2009, 22, 9-15. [CrossRef]

263. Mageney, V.; Baldermann, S.; Albach, D.C. Intraspecific Variation in Carotenoids of Brassica oleracea var. sabellica. J. Agric. Food Chem. 2016, 64, 3251-3257. [CrossRef]

264. Kerrigan-Baumrind, L.A.; Quigley, H.A.; Pease, M.E.; Kerrigan, D.F.; Mitchell, R.S. Number of ganglion cells in glaucoma eyes compared with threshold visual field tests in the same persons. Investig. Ophthalmol. Vis. Sci. 2000, 41, 741-748.

265. Greenfield, D.S.; Bagga, H.; Knighton, R.W. Macular thickness changes in glaucomatous optic neuropathy detected using optical coherence tomography. Arch. Ophthalmol. 2003, 121, 41-46. [CrossRef] [PubMed] 
266. Kim, N.R.; Lee, E.S.; Seong, G.J.; Kim, J.H.; An, H.G.; Kim, C.Y. Structure-function relationship and diagnostic value of macular ganglion cell complex measurement using Fourier-domain OCT in glaucoma. Investig. Ophthalmol. Vis. Sci. 2010, 51, 4646-4651. [CrossRef] [PubMed]

267. Tan, O.; Li, G.; Lu, A.T.; Varma, R.; Huang, D.; Advanced Imaging for Glaucoma Study Gruop. Mapping of macular substructures with optical coherence tomography for glaucoma diagnosis. Ophthalmology 2008, 115, 949-956. [CrossRef]

268. Ventura, L.M.; Porciatti, V. Restoration of retinal ganglion cell function in early glaucoma after intraocular pressure reduction: A pilot study. Ophthalmology 2005, 112, 20-27. [CrossRef]

269. Nork, T.M.; Ver Hoeve, J.N.; Poulsen, G.L.; Nickells, R.W.; Davis, M.D.; Weber, A.J.; Vaegan, N.A.; Sarks, S.H.; Lemley, H.L.; Millecchia, L.L. Swelling and loss of photoreceptors in chronic human and experimental glaucomas. Arch. Ophthalmol. 2000, 118, 235-245. [CrossRef]

270. Hood, D.C.; Raza, A.S.; de Moraes, C.G.; Liebmann, J.M.; Ritch, R. Glaucomatous damage of the macula. Prog. Retin. Eye Res. 2013, 32, 1-21. [CrossRef]

271. Drance, S.M. The early field defects in glaucoma. Investig. Ophthalmol. 1969, 8, 84-91.

272. Alencar, L.M.; Medeiros, F.A. The role of standard automated perimetry and newer functional methods for glaucoma diagnosis and follow-up. Indian J. Ophthalmol. 2011, 59, S53-S58. [CrossRef]

273. Anderson, R.S. The psychophysics of glaucoma: Improving the structure/function relationship. Prog. Retin. Eye Res. 2006, 25, 79-97. [CrossRef]

274. Hood, D.C.; Raza, A.S. Method for comparing visual field defects to local RNFL and RGC damage seen on frequency domain OCT in patients with glaucoma. Biomed. Opt. Express 2011, 2, 1097-1105. [CrossRef] [PubMed]

275. Hood, D.C.; Raza, A.S.; de Moraes, C.G.; Johnson, C.A.; Liebmann, J.M.; Ritch, R. The Nature of Macular Damage in Glaucoma as Revealed by Averaging Optical Coherence Tomography Data. Transl. Vis. Sci. Technol. 2012, 1, 3. [CrossRef]

276. Curcio, C.A.; Allen, K.A. Topography of ganglion cells in human retina. J. Comp. Neurol. 1990, 300, 5-25. [CrossRef] [PubMed]

277. Johnson, E.J.; Vishwanathan, R.; Rasmussen, H.M.; Lang, J.C. Bioavailability of AREDS1 micronutrients from softgel capsules and tablets: A pilot study. Mol. Vision 2014, 20, 1228-1242.

278. Bone, R.A.; Davey, P.G.; Roman, B.O.; Evans, D.W. Efficacy of Commercially Available Nutritional Supplements: Analysis of Serum Uptake, Macular Pigment Optical Density and Visual Functional Response. Nutrients 2020, 12, 1321. [CrossRef]

279. Van Het Hof, K.H.; West, C.E.; Weststrate, J.A.; Hautvast, J.G.A.J. Dietary Factors That Affect the Bioavailability of Carotenoids. J. Nutr. 2000, 130, 503-506. [CrossRef]

280. Castenmiller, J.J.; West, C.E. Bioavailability and bioconversion of carotenoids. Annu. Rev. Nutr. 1998, 18, 19-38. [CrossRef]

281. Broekmans, W.M.; Berendschot, T.T.; Klopping-Ketelaars, I.A.; de Vries, A.J.; Goldbohm, R.A.; Tijburg, L.B.; Kardinaal, A.F.; van Poppel, G. Macular pigment density in relation to serum and adipose tissue concentrations of lutein and serum concentrations of zeaxanthin. Am. J. Clin. Nutr. 2002, 76, 595-603. [CrossRef]

282. Hammond, B.R., Jr.; Ciulla, T.A.; Snodderly, D.M. Macular pigment density is reduced in obese subjects. Investig. Ophthalmol. Vis. Sci. 2002, 43, 47-50.

283. Johnson, E.J.; Hammond, B.R.; Yeum, K.J.; Qin, J.; Wang, X.D.; Castaneda, C.; Snodderly, D.M.; Russell, R.M. Relation among serum and tissue concentrations of lutein and zeaxanthin and macular pigment density. Am. J. Clin. Nutr. 2000, 71, 1555-1562. [CrossRef] [PubMed]

284. Nolan, J.; O’Donovan, O.; Kavanagh, H.; Stack, J.; Harrison, M.; Muldoon, A.; Mellerio, J.; Beatty, S. Macular pigment and percentage of body fat. Investig. Ophthalmol. Vis. Sci. 2004, 45, 3940-3950. [CrossRef] [PubMed]

285. Wang, W.; Connor, S.L.; Johnson, E.J.; Klein, M.L.; Hughes, S.; Connor, W.E. Effect of dietary lutein and zeaxanthin on plasma carotenoids and their transport in lipoproteins in age-related macular degeneration. Am. J. Clin. Nutr. 2007, 85, 762-769. [CrossRef]

286. Lim, C.; Kim, D.-w.; Sim, T.; Hoang, N.H.; Lee, J.W.; Lee, E.S.; Youn, Y.S.; Oh, K.T. Preparation and characterization of a lutein loading nanoemulsion system for ophthalmic eye drops. J. Drug Deliv. Sci. Technol. 2016, 36, 168-174. [CrossRef]

287. Conti, B.; Bucolo, C.; Giannavola, C.; Puglisi, G.; Giunchedi, P.; Conte, U. Biodegradable microspheres for the intravitreal administration of acyclovir: In vitro/in vivo evaluation. Eur. J. Pharm. Sci. 1997, 5, 287-293. [CrossRef]

288. Jaiswal, M.; Dudhe, R.; Sharma, P.K. Nanoemulsion: An advanced mode of drug delivery system. 3 Biotech 2015, 5, 123-127. [CrossRef] [PubMed]

289. Wu, M.; Feng, Z.; Deng, Y.; Zhong, C.; Liu, Y.; Liu, J.; Zhao, X.; Fu, Y. Liquid antisolvent precipitation: An effective method for ocular targeting of lutein esters. Int J. Nanomed. 2019, 14, 2667-2681. [CrossRef] [PubMed] 